The Governance Role of Shareholders and Board of Directors on Firm Performance: An Eclectic Governance-Performance Model*

\author{
Ozgur Ozdemir \\ Microsoft Limited Consulting Services \\ Email: oozdemi@microsoft.com
}

\author{
Erhan Kilincarslan \\ University of Huddersfield \\ Department of Accounting, Finance and Economics \\ Queensgate, HD1 3DH \\ Huddersfield, UK \\ Email: e.kilincarslan@hud.ac.uk \\ Tel: +44 (0) 1484472810
}

Corresponding Author:

Erhan Kilincarslan

This research is extracted and extended from a part of the doctoral thesis, which was written by Ozgur Ozdemir at Birbeck College, University of London.

This research did not receive any specific grant from funding agencies in the public, commercial, or not-for-profit sectors.

Declarations of interest: None

${ }^{\star}$ Forthcoming in "International Journal of Accounting and Information Management" - Accepted on 22 May 2021 


\title{
The Governance Role of Shareholders and Board of Directors on Firm Performance: An Eclectic Governance-Performance Model
}

\begin{abstract}
Purpose - This study examines the governance role of shareholders and board of directors in determining firm performance through an eclectic multi-theoretic model that integrates structure and incentive functions of agency theory and capability aspect of the resource-based view.

Design/methodology/approach - The research model uses a large panel dataset of 2,364 UK firms over the period 2000-2010, and employs alternative specifications of the model to improve robustness.

Findings - The results show that industry experience of major shareholders as a proxy for shareholder capability has a significant positive impact on investee firm performance. The findings also reveal that the lock-in-effect of the largest shareholder has a positive impact on performance, whereas the monitoring effectiveness of shareholders is not associated with ownership concentration. Moreover, the results indicate the underlying capabilities of the board of directors and their impact on corporate performance - particularly, the interlocking directorates of executives have a positive impact on firm performance but those of nonexecutives have a negative one. However, the previous directorship experience of nonexecutives has a positive impact on performance.
\end{abstract}

Research implications - This study presents more comprehensive and complete understanding about the governance-performance relationship beyond the narrow or partial explanations provided by single-theory-based studies or those of investigating the effect of various governance tools separately.

Practical implications - This study provides more insights into capability dimension of shareholders and the role of incentives in motivating shareholders to exercise stronger oversight on the management rather than just using ownership concentration. Hence, the study can serve as a valuable guidance for investors, corporate managers and policymakers.

Originality/value - To the best of our knowledge, this is the first comprehensive study that uses an eclectic philosophical approach, integrating the agency theory and resource-based view, to not only examine the impact of board of directors but also investigate the governance role of shareholders in modern corporations in order to understand how shareholders acquire the requisite skills and information, the best practices and processes, and ultimately use the scarce and inimitable resources that help investee firms in improving their performance.

Keywords: Agency theory, resource-based view, governance-performance model, UK firms.

Paper type: Research paper. 


\section{Introduction}

The relationship between corporate governance and financial performance has been extensively investigated in different disciplines (e.g., economics, finance, management, law and sociology) by numerous researchers (see, e.g., McConnell and Servaes, 1990; Wahal, 1996; Filatotchev et al., 2001; Gompers et al., 2003; Mangena et al., 2012; Peni and Sami, 2012; Singh et al., 2018, among others). This is because the separation of ownership and control especially in widely-held modern corporations creates a space for potential conflicts of interest between shareholders and management (Berle and Means, 1932; Alchian and Demsetz, 1972; Jensen and Meckling, 1976). Given that shareholders hire managers to run the firm on their behalf; theoretically, corporate managers are assumed to perform primarily to maximise the wealth of their shareholders (Ward, 1993; Bishop et al., 2000). In practice, however, the actual behaviour of these managers can have an important impact on firm performance and thus market value - whether they act in the best interests of shareholders or abuse their controlling power at the expense of shareholders' interests. Since corporate governance refers to the ways in which company owners attempt to assure themselves of earning a return on their investment (Fama and Jensen, 1983; Shleifer and Vishny, 1997), it is therefore suggested that an effective governance framework can help mitigate the problems associated with the separation of ownership and control by reducing opportunistic behaviour of managers and hence increasing firm performance and value.

Previous research investigating the shareholder-management relation generally follows two dominant paths: the agency theory and the resource-based view of the firm. In fact, the mainstream is grounded on an agency theory perspective that often focuses on monitoring functions (e.g., board of directors and ownership concentration) and incentive mechanisms (e.g., managerial ownership and performance-based remuneration) in order to align the interests of management with those of shareholders. Such alignment leads to good internal governance and decreases agency problems, therefore improves firm performance (Demsetz and Villalonga, 2001; Filatotchev et al., 2001; Chen et al., 2008; Lin et al., 2009).

The second research stream is driven by the resource-based view of strategic management. This resource-based view aims to provide an association between board of directors and corporate performance through directors' perceived ability to reduce environmental uncertainty - the external linkages of directors connect their firms to a wider environment and other firms in the market, and supply access to potential business partners, production facilities, and investments (Barney, 1986; Dierickx and Cool, 1989; Peteraf, 1993; Mahoney and Pandian, 1992). However, it is argued that none of these theories fully explains the determinants of effective corporate governance or the association between governance and performance single-handedly. For instance, the control focus of the agency theory ignores boards' ability to monitor and the ability focus of the resource-based view ignores the role of incentives in ensuring good corporate governance. Thus, each theory provides a partial explanation (Nicholson and Kiel 2007; Jackling and Johl, 2009).

Another important issue with the extant corporate governance studies using both the agency and resource-based views is that they mostly ignore the underlying capabilities of shareholders as well as neglecting the incentives for shareholders in determining good governance (Richardson, 1972; Granovetter, 1985; Perrow, 1988; Hillman and Dalziel, 2003). In identifying shareholders' role, the vast majority of research has generally focused on the ownership concentration (De Miguel et al., 2004; Mura, 2007; Chang et al., 2008; Lin et al., 2009) and suggested that large block outside ownership has a counter-balancing effect on managerial opportunism (Filatotchev et al., 2001). Nevertheless, ownership proportion alone 
cannot capture such things as shareholder knowledge, experience and skills, despite the fact that shareholders can accumulate knowledge and skills through their investments in the market (Douma et al., 2006; Chuang and Wu, 2011), and ultimately improve the firm's performance. Yet, ownership concentration is not a sufficient proxy measuring the incentives for shareholders due to the factors such as the emergence of cross shareholdings, in which case the impact of incentives has been for shareholders to better monitor the individual firms (Maug, 1998; Thomsen and Pedersen, 2000) and the fact that ownership mindset is determined through a value maximising approach driven by portfolio structure (Lskavyan and Spatareanu, 2006). Given that the motivation of agency explanation on control and the information and the focus of the resource-based view on ability and resourcing are not mutually exclusive, it is recommended that the agency theory should be coupled with complementary approaches to provide a better empirical perspective (Eisenhardt, 1989). Similarly, Hillman and Dalziel (2003) emphasise the importance of integrating these two dominant theories for a better explanation of the governance-performance association, because integration overcomes the current myopia in the two dominant theories.

Accordingly, we aim to examine the governance role of shareholders and board of directors on firm performance through an eclectic multi-theoretic model that is designed to supply more comprehensive understanding about their impact in determining corporate performance, and hence to contribute new evidence beyond the narrow or partial explanations provided by the existing research. In particular, our eclectic analytical governanceperformance model assumes; (i) good governance is a function of shareholders and board of directors, (ii) integrates the dominant agency theory and resource-based view, and (iii) considers such factors regarding structure and incentive (agency theory) and capability (resource-based view) aspects of shareholders and board of directors affecting governance and thus performance in widely-held modern corporations. Furthermore, we empirically test our research model using a large panel dataset over the period of 2000-2010. Our research sample has 2,364 non-financial firms listed on the London Stock Exchange (LSE) and covers both international large firms listed in the Main Market, and small and growing firms listed on the Alternative Investment Market (AIM).

Our study contributes to the corporate governance literature in several ways. First, we extend the existing agency-based empirical research that solely relies on monitoring of the management by including incentive focus of the agency argument as well as incorporating the resource-based view on both shareholders and board of directors. This eclectic approach of integrating the two dominant theories augments the current incomplete explanations supplied by single-theory studies. Second, although shareholders are the ultimate owners and receive the outputs of firms which are created by managerial actions, their governance role beyond a monitoring rationale is not sufficiently examined - hence, the extant literature lacks shareholders' actual impact in determining firm performance. In this respect, utilising a resource-based-explanation perspective, we attempt to gain more insights into the capability dimension of shareholders and the ways how they can accumulate the knowledge and experience needed in order to exchange views and information on strategy and performance. Third, by employing the lock-in effect (i.e., the fraction of a given equity investment value to the shareholder's overall portfolio), our study provides better understanding about the role of incentives in motivating shareholders to exercise stronger oversight on the management. This is because the existing governance-performance models are biased since using ownership concentration does not increase understanding of the impact of shareholders' portfolio characteristics as incentives for better monitoring due to the emergence of large financial institutions that invest across numerous equities. Thus, we argue that the lock-in effect provides a better incentive for a shareholder to monitor than a traditional firm-level ownership 
concentration. To the best of our knowledge, this is the first comprehensive study that uses an eclectic philosophical approach, integrating the agency theory and resource-based view, to not only examine the impact of board of directors but also investigate the governance role of shareholders in modern corporations in order to understand how shareholders acquire the requisite skills and information, the best practices and processes, and ultimately use the scarce and inimitable resources that help investee firms in improving their performance.

\section{Theoretical Framework}

\subsection{The agency theory on corporate governance and firm performance}

The traditional agency literature focuses on two aspects of the owner (principal)-manager (agent) conflict to provide testable hypotheses (Darrough and Stoughton, 1986; Eisenhardt, 1989; Page, 1991). These are moral hazard and adverse selection. The problem of moral hazard arises in cases where the management do not provide the necessary efforts as contractually agreed and this cannot be observed by the shareholders due to their inability to observe managerial actions. In the corporate system, the principal's and agent's levels of information are different and the information asymmetry between the principal and the agent adversely affects the interests of the principal. In the presence of moral hazard and adverse selection, managers can extract personal benefits and introduce agency costs at the expense of shareholders (Alchian and Demsetz, 1972; Jensen and Meckling, 1976). These costs are traditionally known as monitoring costs (i.e., cost of having a board of directors and external auditors), bonding costs (e.g., contractual obligations that restrict the agent's actions), and residual losses (i.e., costs incurred due to the divergent interests of the agents). A considerable amount of work has been published on this and a list of conventional mechanisms has been proposed to resolve the agency conflict, which can be classified into three main categories. These are structural constituents of ownership, control, and managerial incentives.

Publicly-listed corporations in the Anglo-Saxon capital markets usually have dispersed ownership structures; however, it is contended that dispersed ownership causes weak monitoring on management actions and might create a free-riding problem (Maug, 1998; De Miguel et al., 2005). Previous studies indicate that large shareholders, also called blockholders or major shareholders, have more motivation and ability to act as an effective monitoring mechanism on management due to their commitment and marginal dependence on the return on investment. Therefore, the existence of such large shareholders can mitigate the free-rider problem of monitoring managers and reduces the principal-agent conflicts (Grossman and Hart, 1980; Demsetz and Lehn, 1985; Shleifer and Vishny, 1986). Moreover, Thomsen and Pedersen (2000) detect that the identity of the large shareholders is another important factor affecting management behaviour and thus firm strategy, goals and performance. The empirical research concerning the link between ownership structure and firm performance provides mixed results. For instance, Lin et al. (2009) and Thomsen and Pedersen (2000) find that ownership concentration has a positive impact on the shareholder value but this does not hold for higher ownership levels, indicating tunnelling activities by the largest shareholders. Chang et al. (2008), Mura (2007) and Filatotchev et al. (2001) find a negative relation, while Florackis (2005) reports no correlation.

Numerous studies have examined the impact of corporate boards in organisations and have reported significant associations between their governance role and various areas such as the auditor quality choice/fraud reporting (Karim et al., 2013; Abu Khadra and Delen, 2020), dividend payout policy (Al-Najjar and Kilincarslan, 2016; Elmagrhi et al., 2017), earnings characteristics/quality (Ji et al., 2015; Yu and Wang, 2018), firm performance/valuation (Brown 
and Caylor, 2006; Siddiqui, 2015; Khosa, 2017), corporate social responsibility and environmental disclosures (Ullah et al., 2019; Kilincarslan et al., 2020), and risk taking behaviour measured by credit risk (Ko et al., 2019) or R\&D intensity (AlHares et al., 2020). Indeed, the agency-based-explanation framework emphasises the control role of the board of directors in monitoring executives' discretion and suggests that internal governance mechanisms provided by the structure of the board (e.g., board size, board independence and chairman/chief executive officer (CEO) duality) help to ensure that boards serve as a trustworthy agent to maximise shareholders' wealth and increase firm value (Yermack, 1996; Weir and Laing, 2003; Florackis, 2008; Guest, 2009). The Cadbury Report (1992) stresses that corporate boards both lead and control the businesses and hence have the collective ability to provide effective governance practices through their leadership and scrutiny. The empirical evidence on the control role of the boards is rich in context but mixed. Examining a large dataset of 2,746 UK firms, Guest (2009) does not find any association between the monitoring role of the board and firm performance but detects a negative impact of board size on performance. This suggests that larger boards have communication and decision-making problems. However, Brown and Caylor (2006) find a positive relationship between board size and market performance. Furthermore, Cotter and Silvester (2003) and Vafeas and Theodorou (1998) find no clear link between board independence and firm performance. Dalton et al. (1998), who provide a detailed meta-analysis of 54 empirical studies, and Klein (1998) report no statistical support for an association between board composition, board leadership and firm performance.

A branch of research has identified a connection between managerial incentives and corporate performance, claiming that managerial incentives supply the agents' commitment to ensuring high returns of the business as they also benefit (Baber et al., 1996; Conyon and Peck, 1998; Johnston, 2002; Hartzell and Starks, 2003; Goergen and Renneboog, 2011). Managerial incentives cover managerial ownership and remuneration. The "convergence of interest hypothesis" states that managerial ownership increases firm value by bringing together the interests of management and shareholders (Cole and Mehran, 1998; De Miguel et al., 2005; Florackis, 2008; Chen et al., 2008). Contrarily, "managerial entrenchment perspective" argues that when management hold a substantial number of shares, they become more powerful and may tend to expropriate the firm's resources for their personal benefits or even try to take over the firm. A high level of managerial ownership might, therefore, negatively affect the firm's performance. Florackis (2008), De Miguel et al. (2005), Cole and Mehran (1998), and Wright et al. (1996) report a positive association, and Short and Keasey (1999) and Hermalin and Weisbach (1991) report a non-linear relationship between managerial ownership and firm performance. Furthermore, prior studies present sufficient evidence to suggest a relationship between executive pay and performance (e.g., see, Baber et al., 1996; Hartzell and Starks, 2003; Khan et al., 2005; Ozkan, 2011, among others). Gregg et al. (2010) find an asymmetric association between pay and performance. In their findings, payperformance elasticity is higher in those companies with high stock returns. In another study, Ozkan (2011) reports that a 10\% increase in shareholder returns is associated with an increase of $0.75 \%$ in the CEO's cash compensation. Hartzell and Starks (2003) investigate the link between institutional investors and executive compensation and find that institutional ownership concentration is positively related to the pay-for-performance sensitivity of executive compensation and negatively related to the level of compensation. These findings support the notion that managerial incentives have a role in mitigating the agency problem. Table 1 summarises the most cited governance-performance research applying an agency perspective.

(Insert Table 1 about here) 


\subsection{The resource-based view on corporate governance and firm performance}

The second research stream is derived from the resource-based view and concerns the interaction between the organisation and the environment as mediated through the board of directors. In this perspective, the board has the role of understanding the resource requirements of firms and evaluating the environment from which critical and scarce resources can be acquired (Pferrers and Salancik, 1978). In one of the most cited studies, Zahra and Pearce (1989) acknowledge that the association between the board of directors and firm performance works through directors' ability to extract resources for companies' operations and this occurs through the board's role of supplying trustworthy and reliable information, introducing the best business practices and processes from other businesses, and ultimately accessing a wide range of resources. The linkages of directors to the external environment are central in achieving these objectives and the extent of external linkages are mostly measured through interlocking directorates (Burt, 1980; Haunschild and Beckman, 1998; Shropshire, 2010).

Interlocking directorates (in other words, multiple directorships) occur when a director sits on the boards of more than one corporation (Burt, 1980; Stuart and Yim, 2010). Interlocks have a role in information acquisition and interpretation (Rao et al., 2000) and can provide access to critical business information from other organisations which may not be available in the public domain. In particular, information from similar and successful organisations including business partners and competitors may help the focal organisation to implement best practices and processes. Haunschild and Beckman (1998) argue that the information from interlocking directorates is more influential if the director is working in a similar organisation. By employing industry interlocks, corporations gain access to the resources utilised by other organisations to which the focal organisation's multiple directors are linked. They help firms to scan a wider environment and decrease the cost of various transactions such as price and resource search costs (Bazerman and Schoorman, 1983) and allow organisations to mimic the behaviours of similar organisations which are observable to them (Galaskiewicz and Wasserman, 1989). Interlocks are among the most widely deployed mechanism to disseminate business structures (Shropshire, 2010), share professional experience, and gain access to outside resources.

In contrast to the benefits outlined above, however, interlocks might create an additional burden on the directors and prevent them from undertaking their monitoring role. This is because interlocks allow for unified political agendas by creating common business objectives and hence can be used to monopolise the market by giving control to the same group of directors across companies (Salinger, 2005; Asimakopoulos, 2009; Bowman, 2009). The Council of Institutional Investors (1998) suggests that full-time directors should not serve on more than two other boards, and no person should serve on more than five boards. It also recommends that CEOs should not serve as a director in more than two for-profit companies. The empirical evidence on the impact of interlocking directorates is inconclusive. Using a sample of Dutch firms, Non and Franses (2007) find that interlocks have a negative impact on firm performance, while Ferris et al. (2003) report no evidence that interlocks are a burden on the independent directors that ultimately affects their monitoring effectiveness and commitment to their jobs. Nevertheless, Nicholson and Kiel's (2007) conclude that boards view linkages to the external environment as an important value-adding characteristic.

In the context of UK market, the impact of interlocks possibly differs from the majority of the research mentioned above. This is because the ownership structure is generally dispersed among small shareholders in the UK as in the USA that is different from those of other developed countries such as Canada, Japan and Western Europe. Thus, publicly-listed 
UK firms operate under a corporate governance setting characterised by a significant degree of managerial control (Davies et al., 2005; Florackis and Ozkan, 2009). However, the studies conducted in other markets deal with the influence of interlocks who are being appointed by controlling shareholders in where the prominent agency problems stem from the conflicts between controlling and minority owners (Bertoni and Randone, 2006). In the case of our study, since ownership is diffused and the corporate control remains concentrated in the hands of managers, we conjecture that interlocks might not be contributing to firm performance because they are appointed by executive directors and executives have the potential to expropriate firms' resources. Given that executive ownership typically has a U-shaped relation to firm performance in the UK (Short and Keasey, 1999; Davies et al., 2005), the appointing of interlocks by executive directors might increase the exposure of shareholders to agency costs. Therefore, we set forth the following hypothesis:

H1: The extent of the linkages between the board of directors and the external environment is negatively associated with firm performance.

Pfeffer and Salancik (1978, p.162) state that the purpose of appointing an outsider might vary but the key is "appointing people with managerial skills to provide the organisation with managerial expertise." Boards require specialist knowledge and expertise in order to operate effectively (Forbes and Milliken, 1999). Kroll et al. (2008) argue that boards' reliance on the vigilance of directors restricts board effectiveness. Directors should have the appropriate knowledge in order to supply monitoring, and such knowledge can be gained through experiential learning. Board vigilance per se is necessary but may not be sufficient for understanding the effectiveness of the board of directors. Their empirical findings support the suggestion that vigilance and relevant experience give directors an ability to supply both monitoring and advisory services in corporations. Moreover, experience is found to be particularly important in determining the strategic decisions taken by a board of directors (Hambrick and Mason, 1984; Geletkanycz and Hambrick, 1997). Field and Mkrtchyan (2017) finds that prior involvement of directors in acquisitions is associated with significant increases in acquisition performance. In this regard, managerial experience is central in understanding the impact of the board of directors on firm performance (Hillman and Dalziel, 2003). Hence, our second hypothesis is constructed as follows:

H2: Managerial (executive/non-executive) experience is positively associated with firm performance.

\subsection{Shareholder view on corporate governance and firm performance}

The agency-based literature uses ownership structure to address shareholders' impact on governance and firm performance, but it neglects two aspects of the shareholders' role in corporations. First, shareholders have differing abilities in regard to performing their responsibilities as outlined by the Cadbury Report (1992) and the UK Stewardship Code (2010). Exchanging views and information on strategy requires them to be informed about the business and industry. This is possible as a result of awareness of similar businesses including the investee firms' partners and competitors. Therefore, shareholders' resources and their linkages to the environment are crucial in terms of their stewardship role. Second, shareholders require incentives just like management in order to conduct their monitoring role due to the costs associated with monitoring activities (Parkinson, 2002). Prior research using ownership concentration as a proxy for the strength of shareholders' monitoring failed to determine a causal explanation for shareholders' passivity. Large investors have stakes in numerous firms and a high level of ownership in a firm does not necessarily mean a high 
marginal impact on the overall portfolio of the shareholder. Existing studies ignore these underlying characteristics of the investors' portfolio, focusing only on the major shareholder's ownership concentration. Our contention is thus that shareholders can exercise their ownership rights in the presence of the requisite capabilities and incentives that enable them to exercise their rights.

\subsection{A resource-based approach to the capability of shareholders}

The Cadbury Report (1992) defines the first role of shareholders as exchanging views and information on strategy and performance. The UK Stewardship Code (2010) extends the role of shareholders - in particular, institutional investors - beyond monitoring and acknowledges them as stewards of the investee firms. However, the control focus of the agency theory underestimates shareholders' capabilities in contributing to investee firms' strategy and performance through exchanging views and information, and ultimately being an effective steward. But, how we can explain the ways that enable shareholders to obtain requisite capabilities to improve investee firm performance?

Large shareholders are mostly composed of professional money management companies which invest the money of individuals and organisations on their behalf (Brancato, 1997). These companies include investment advisors, pension funds, mutual funds, insurance companies, and other investment firms. Their investments span multiple companies, which allows them to access information and resources in different firms and industries. The resource-based view of strategic management argues that a firm can gain competitive advantage by acquiring resources which are difficult to obtain for other firms. Organisations gain access to outside resources using their networks within the market and industry, and they can exchange and use these resources in achieving their objectives (Pfeffer and Salancik, 1978; Cropanzano and Mitchell, 2005). So, a resource-based approach to shareholders may help us to understand how shareholders can acquire the requisite skills and information, best practices and processes, and ultimately scarce and inimitable resources that may help their investee firms to improve their performance. All this can be done through the implications of their multiple shareholdings.

Studies utilising a resource-based view on shareholders are limited and relatively new in the management literature. Chuang and Wu (2011) contend that the external linkages of shareholders are crucial in supplying resourcing capabilities from outside shareholding networks to investee firms. They argue that the networks of large shareholders improve investee firm capabilities by bringing in outside resources and teaching. In particular, shareholdings within the same industry - similar to industry directors - are more crucial because large shareholders not only bring capital to investee companies but can also supply industry knowledge and experience. They can thus contribute to the business and help investee firms in achieving a competitive advantage in the market through their industry linkages. North (1990) argues that shareholders' economic activities through both formal and informal channels construct an institutional environment for the exchange and distribution of industry resources. In a similar study, Douma et al. (2006) suggest that resourcing heterogeneity among shareholders has a material impact on firm performance and this is mostly driven by access to resources within the same industry. Further, Bazerman and Schoorman (1983) argue that, in order to be successful, an organisation must increase its power relative to the suppliers of raw materials and purchasers, and conclude that industry knowledge on the part of shareholders helps investee firms to gain access to cost-effective suppliers of services and to materials that provide efficiencies in production. 
Industry interlocking shareholders - similar to industry interlocks - enable investee firms to learn about the best practices and processes implemented by similar organisations hence, mimicking the behaviours of successful competitors and partners, deploying efficient business structures, sharing experiences, and ultimately gaining access to outside resources. This may help shareholders to move beyond their traditional monitoring role as suggested by the Stewardship Code (2010), and gives shareholders the capacity to exchange views and information on strategy and engage with the investee firms on business issues. Based on the above discussion regarding the resource-based view, we expect that industry shareholdings help improve investee firm performance. Therefore, we hypothesise that:

H3: The extent of the linkages between major shareholders and the external environment is positively associated with firm performance.

\subsection{A convergence of interest hypothesis to understand incentives for shareholders}

The existing literature suggests that shareholders have an ability to have strong oversight over management but only a limited number of studies research the use of this ability. Gillan and Starks (2003) acknowledge the role of shareholders as governance control mechanisms and distinguish the ways they can influence management into two categories. They suggest that shareholders can influence the activities of management directly through their high level of ownership proportions, having an impact on management's strategies and the gains of the short- and long-term decisions made by trading investee companies' shares on the stock market. Second, shareholders can communicate with management directly on corporate matters, initiate shareholder proposals at the Annual General Meeting, and vote against corporate positions due to the large numbers of shares they own. However, the findings mostly confirm that shareholder monitoring is unlikely to happen in the dispersed ownership structure of Anglo-Saxon corporations. In highly diffused ownership structures, an individual owner bears the cost of the monitoring but the returns are enjoyed by all of the shareholders. Hence, the literature on the subject mostly associates shareholders with monitoring passivity due to inadequacies in exercising ownership rights, subsequently limiting their influence on investee companies (OECD, 2011). Previous research has mainly focused on ownership concentration as a proxy to understand the impact of major shareholders on firm performance (McConnell and Servaes, 1990; Thomsen and Pedersen, 2000; Mura, 2007; Florackis, 2008). It is widely accepted that higher levels of ownership concentration push powerful shareholders towards monitoring, accessing the processes and tools necessary to convey their concerns, and thus limit agency problems, in contrast to small investors who do not have these opportunities (Kesner, 1989). Such studies use the ownership concentration as a proxy through which to understand the incentives for shareholders to provide effective oversight of management. However, the ownership concentration does not take the underlying allocations of the shareholders' equity investment portfolio into consideration, and therefore the incentive role it plays is a topic of debate.

Portfolio allocation determines the overall return of shareholders once they deploy costly monitoring mechanisms, and the return might be small even though the ownership concentration is higher in a specific firm. Thus, it is important to understand the portfolio characteristics of shareholders investing in a number of equities. Markowitz (1952) argues that the portfolio selection process aims to maximise the anticipated returns - large shareholders invest in a number of equities whose overall performance lead them to overall gain or loss. Despite theoretical and empirical evidence in favour of diversification, investors still hold significant shares in a small number of firms (Zweibel, 1995). Therefore, a shareholder's 
portfolio selection process determines the marginal impact of the individual investee firms' performance on the shareholder's overall portfolio. Maug (1998) employs the ratio of the firm's investment value to the largest shareholder's portfolio value as a proxy of the lock-in effect. The lock-in effect is larger when the investment ratio of a specific shareholding to the total portfolio value of the shareholder is higher. Kahn and Winton (1998) and Zweibel (1995) take the approach that the level of monitoring activities is determined by the costs and benefits of monitoring, and indeed find that blockholders potentially have the benefit of private monitoring. This benefit is higher in the case of having portfolios focused on a small number of firms and the associated larger individual stock lock-in effect. In contrast, extensive diversification of stocks undermines shareholder monitoring and does not allow them to exercise their stewardship roles. Following the above discussion, we set forth the following hypothesis:

H4: The portfolio-shareholding investment ratio (lock-in effect) of the largest shareholder is positively associated with firm performance.

Overall, we establish a multi-theoretic integrated analytical framework in order to explain the governance role of shareholders and board of directors in determining the investee firm performance. As Figure 1 illustrates, our research model provides a comprehensive and complete approach to improve the partial explanations supplied by the single-theory-based research. Specifically, our model integrates structure and incentive functions of agency theory and external linkages focus of the resource-based view. By doing so, we attempt to cover a formerly neglected dimension - namely, the role of shareholders, those capabilities that enable them to engage with the investee firms and incentives to encourage shareholders towards exercising their monitoring role.

(Insert Figure 1 about here)

\section{Data and Methodology}

\subsection{Data sample}

For our empirical analysis, we construct a large panel dataset of listed non-financial UK corporations over the period 2000-2010. Using the London Stock Exchange (LSE)'s official website, we specifically focus on the LSE Main Market (MAIN) and LSE Alternative Investment Market (AIM) to provide a better representation of large and small capitalisation firms. We then exclude financial sector companies (Industry Classification Benchmark (ICB) code 8000) and those firms incorporated outside the UK. We collect the data from multiple sources due to the difficulties of obtaining the corporate governance data from a single source. By manually identifying, information on director appointments, remuneration and ownership structure is obtained from the Hemscott database and the data on shareholders, such as identities, investment strategies, policies and transactions, are derived from the Thomson One Banker database, whereas Datastream database serves as the source for compiling data on accounting and financial variables. We match the Hemscott, Thomson One Banker and Datastream data using the Stock Exchange Daily Official List (SEDOL) codes and International Security Identification Numbers (ISIN) of the companies. Prior to our analysis, we also crosscheck the validity of the corporate governance data with the LSE information releases, PricewaterhouseCoopers Corporate Register and companies' annual reports.

Next, we narrow our sample down to firms whose data are available on all these databases. At this point, it is worth noting that the sample period starts from 2000 as a result of the data availability - given the scope of our study and the aim of constructing a large and 
detailed panel dataset, we were unable to collect sufficient observations regarding directors' and shareholders' information in early years. Due to the great difficulties in the collection of governance-related data used in this research which are not publicly available online, we only manage to extend the time horizon until the end of 2010. Indeed, at the beginning of the millennium, a series of global corporate scandals (e.g., Enron and Worldcom in the US, Parmalat and Cirio in Italy, and Ahold in the Netherlands) took place and the following ten years saw a rapid speed of change in technological advances, shorter product life cycle and international competition. All of these developments and changes have led to more challenges in corporate governance and have placed more emphasis on good corporate governance in a globalised economy. Accordingly, the period 2000-2010 provides a unique setting in which to examine the governance roles of board of directors and shareholders on firm performance in the UK during the first decade in the 21st Century. Nonetheless, there is, of course, no doubt that performing our analysis on recent time periods would be a promising research avenue and this study can be a valuable baseline for such future work. Lastly, we include all the remaining companies, which were either delisted or newly listed at different times during the research period, in our sample to avoid possible survivorship bias.

Consequently, our final sample consists of 2,364 non-financial UK firms between 2000 and 2010 , with a minimum of $89 \%$ coverage of listed-companies in 2000 and a maximum of $99 \%$ coverage rate in 2009 and 2010. The final sample represents 15 broad industries (based on ICB codes) of which the most common types are industrial goods and services (23.6\%), technology (14.2\%), travel and leisure (9.2\%) and media (8.6\%), which constitute about $56 \%$ of all firms.

\subsection{Research design, model and variables}

In order to test the research hypotheses $(\mathrm{H} 1$ through $\mathrm{H} 4)$ based on our eclectic multi-theoretic governance-performance framework, we formulate a mathematical equation that helps explain the governance role of board of directors and shareholders in determining corporate performance. First, we employ Tobin's $Q$, which is the most popular proxy to measure firm performance as the dependent variable. Since our study aims to provide a more comprehensive and complete explanation for the governance-performance relationship, we then define a set of explanatory variables proxying for the governance effects of structure, incentive and capability aspects of board of directors and shareholders on corporate performance. Given that our research sample consists of both international large corporations traded in the LSE MAIN and comparatively smaller growing firms listed on the LSE AIM from 15 different industries, and covers the relatively long time period between 2000 and 2010, we third attempt to control for the firm size, industry-specific effects and time-varying (observed and unobserved) factors by adding control variables into our equation.

We further consider the critical issue of endogeneity while constructing our research model. Thus, we use one-year lagged values for all independent variables (except industry and year dummies) to ensure that the governance impact of board of directors and shareholders are predetermined with respect to firm performance in order to mitigate endogeneity problem. The reason is that using the lag values prevents the simultaneity bias since the current value of dependent variable cannot impact any of the lagged independent variables. This also helps avoid a situation in which independent variables are correlated with the error term because the lag values cannot be correlated with the current year error term although they are highly correlated with the current values of independent variables. 
Accordingly, employing the pooled ordinary least squares (OLS) econometric approach, we specify the following empirical equation (Model 1):

$$
\begin{aligned}
\text { TOBINQ }_{i, t}= & \alpha_{0}+\beta_{1} \text { BOARDSIZE }_{i, t-1}+\beta_{2} \text { BINDEPENCE }_{i, t-1}+\beta_{3} \text { DUAL }_{i, t-1}+\beta_{4} \text { DRCTRSHIP }_{i, t-1}+ \\
& \beta_{5} \text { TASKEXP }_{i, t-1}+\beta_{6} \text { OTHERTASKEXP }_{i, t-1}+\beta_{7} \text { INDUSTRYEXP }_{i, t-1}+ \\
& \beta_{8} \text { SAMEFIRMEXP }_{i, t-1}+\beta_{9} \text { DIROWN }_{i, t-1}+\beta_{10} \text { DIROWN }_{i, t-1}+ \\
& \beta_{11} \text { REMUNERATION }_{i, t-1}+\beta_{12} \text { OWNCON }_{i, t-1}+\beta_{13} \text { SHRINTERLOCKS }_{i, t-1}+ \\
& \beta_{14} \text { SHRLOCKING }_{i, t-1}+\beta_{15} \text { FIRMSIZE }_{i, t-1}+\sum_{j=1}^{N} \beta_{j} \text { INDUSTRY }_{j, i, t}+ \\
& \sum_{t=1}^{T} \beta_{t} \text { YEAR }_{i, t}+\varepsilon,
\end{aligned}
$$

where TOBINQ represents Tobin's $Q$ as the dependent variable (firm performance). The three main types of explanatory variables (i.e., board, shareholder and control variables) as follows: BOARDSIZE (board size), BINDEPENCE (board independence) and DUAL (CEO/chairman duality) are the measures for board structure. External linkages and managerial experience of the board of directors are used as the proxies for board capability, which are DRCTRSHIP (average directorship per director), TASKEXP (the same task experience of the director), OTHERTASKEXP (other task experience of the director), INDUSTRYEXP (industry experience of the director) and SAMEFIRMEXP (the director's board experience in the same firm). Board incentives include DIROWN (directorial ownership), DIROWN ${ }^{2}$ (directorial ownership squared) and REMUNERATION (executive director pay). Furthermore, OWNCON (shareholder ownership concentration), SHRINTERLOCKS (major shareholders' industry shareholdings) and SHRLOCKNG (larger shareholder's locking ratio) are employed to measure for the shareholder structure, shareholder capability and shareholder incentives, respectively. Lastly, the control variables are FIRMSIZE (firm size), INDUSTRY (industry dummies) and YEAR (yearly dummies). The list of all research variables used in our empirical analysis and their definitions are provided in Table 2.

(Insert Table 2 about here)

\section{Empirical Results and Discussion}

\subsection{Descriptive analysis}

In this section, we provide descriptive statistics for our research variables gathered from a sample of 2,364 unique non-financial LSE-listed firms representing 15 broad industries over the period 2000-2010. Figure 2 illustrates the industry-level and overall Tobin's Q (firm performance) averages. It reveals that the overall average value of Tobin's $Q$ is 1.78 , which is relatively higher than that reported for other UK studies such as Mura (2007), Guest (2009) and Dong and Ozkan (2008) - i.e., 1.56, 1.53 and 1.68, respectively. However, it is noticeably less than the mean of 1.96 reported by Davies et al. (2005) but is almost identical to the mean value of 1.77 that Ozkan (2011) reported in the UK market. In particular, the LSE firms operating in the "health care" industry show the best performance, followed by those from the "technology" and "auto and parts" industries (having the mean Tobin's Q of 2.48, 2.18 and 2.12, respectively). The firms in "construction" and "personal and household goods" industries have the lowest averages (with 1.29 and 1.31, respectively) and thus reveal the lowest performance. 
Table 3 displays summary statistics for board structure, managerial ownership and remuneration. Consistent with the studies of Florackis (2008), Guest (2009) and Kilincarslan and Ozdemir (2018), the mean board size is 6.44 but the total number of directors on UK boards shows a decreasing trend over the period, averaging 6.97 in 2000 compared to 6.30 in 2010. On average, UK boards consist of 3.1 executives (48.14\%) and 3.34 non-executives (51.86\%), and this is on a par with that reported by Gregg et al. (2010) (48.63\% executives and $51.27 \%$ non-executives for UK firms) - in fact, our evidence reveals that the existence of non-executive directors on board increases from 3.28 (46.5\%) in 2000 to 3.55 (54.76\%) in 2010. Nevertheless, it still falls well short of Cadbury's (1992) recommendation to have nonexecutives making up at least two-thirds of UK boards. The statistics further reveal that the overwhelming majority of the UK firms (93\%) separates the roles of CEO and chairman, whereas few (7\%) having a CEO who also chairs the board, which is very similar to those reported by Florackis (2008) and Florackis and Ozkan (2009) in the UK.

Moreover, Table 3 presents that the overall executive director ownership is $10.39 \%$, which is similar to comparable UK studies - e.g., Dong and Ozkan (2008) (10.47\%) and Florackis (2008) (10.68\%), but relatively higher than Florackis and Ozkan (2009) who report average executive ownership of $8.98 \%$. It is observed that executive director ownership decreases from an average of $12 \%$ in 2000 to $8.85 \%$ in 2010 and this decreasing trend is consistent with Mura (2007), Florackis and Ozkan (2009) and Ozkan (2011). As reported, during the 2000-2010 period for our sample firms, the mean share ownership of non-executive directors is $4.22 \%$, similar to the mean non-executive ownership of $4.06 \%$ provided in Florackis (2008). In contrast to executive ownership, non-executive ownership however exhibits an increasing trend over the period from $3.71 \%$ in 2000 to $4.83 \%$ in 2010 and this upward tendency is in line with Mura (2007). Similarly, using the log of the retail price index (RPI)adjusted total cash salary and bonus pay of executive directors, the results detect a continuous increasing trend in executive remuneration from 5.61 in 2000 to 5.79 in 2009 - indeed, this finding is consistent with Florackis and Ozkan (2009), Gregg et al. (2010) and Ozkan (2011) who report that base salary and bonuses of UK executives has increased noticeably over time during their sample periods (i.e., 1999-2005, 1994-2006 and 1999-2005, respectively).

(Insert Table 3 about here)

Table 4 presents the results of the analysis based on our directors' database that covers 32,504 directorships from 20,363 different individual directors who worked as executives and/or non-executives for at least one year in a firm over the research period. Panel A of Table 4 reports the director-level calculations such as the average number of directorships held by executive and non-executive directors, chairman, CEO and CFO roles across years. Panel $B$ shows the analysis of firm-level multiple directorates for executive and non-executive directors and chairmen. At first glance, the mean directorships occupied by executive and nonexecutive directors are 1.10 and 1.55, respectively, whereas a board member holds 1.35 directorships during our research period - Ferris et al. (2003), in their US-based research using a large panel data set, report a higher average of 1.60. The results further illustrate that the mean of directorships held by chairmen is 1.64 that is well above the director average. The average maximum directorship owned by any director and the average percentage of directors who have held three or more directorships over a decade are 2.39 and $8 \%$, respectively - both of these figures are lower than the US averages of 3.12 and $14.97 \%$ reported by Ferris et al. (2003). Panel C of Table 4 displays the overall statistics for multiple directorships across different indices (i.e., FTSE 100, FTSE Mid-250 and FTSE 350) and markets (i.e., LSE's MAIN and AIM) in order to understand the underlying characteristics of director movements over the 
entire study period. The results reveal that $48 \%$ of FTSE 100 directors did not work in a firm outside the FTSE100 and this ratio is 35\% for the FTSE Mid-250 and $57 \%$ for the FTSE 350. About $82 \%$ of MAIN directors and $80 \%$ of AIM directors only worked in the MAIN and AIM markets. Given that director movements are associated with the knowledge and experience transfers of multiple directors across different corporations and considering the resourcedependence perspective, our evidence detects a low level of cross-market appointments through multiple directorships.

\section{(Insert Table 4 about here)}

Table 5 shows a summary of the experience levels of executive and non-executive directors from three different perspectives: task experience, industry experience and firm experience. First, their past experience in the same role is observed. This includes the past executive directorship experience of executive directors in other firms, and non-executive directorship experience of non-executive directors in other firms. Other role experience means executive directorship experience in the case of non-executive directors and non-executive directorship experience for executive directors. Both the same role and other role experience are measured using the average number of directors with the experience, the average number of different firm experience, and the average number of firm-year experience prior to the director's current role. About $23 \%$ of non-executive directors had previous non-executive directorship experience compared to $6 \%$ of executive directors' having previous executive directorship experience. $13 \%$ of non-executive directors had previous executive directorship experience compared to $7 \%$ of executive directors' previous non-executive directorship experience. Non-executive directors' industry experience ( 0.5 director per firm) is greater compared to the executives' industry experience ( 0.16 directors per firm). Comparatively low non-executive and executive directors have same-firm experience.

\section{(Insert Table 5 about here)}

Moreover, using the Hemscott database, we detect 11,752 major owners of our sample of 2,364 LSE companies, who hold shareholdings of these companies above the $3 \%$ ownership disclosure threshold level in any time during our research period. We manually identify the identity of such large shareholders and classify 3,588 of them as being institutional investors (e.g., insurers, pension and mutual funds, banks and investment firms) and the remaining 8,164 as being other blockholders (e.g., individuals, limited companies, non-profitorganisations and government). Then, we provide statistics for the ownership and shareholder investment characteristics, as illustrated in Table 6. The results show that ownership concentration has been increasing steadily across the years from 2000 to 2010, although it is measured at different threshold levels (i.e., $3 \%, 5 \%$ and $10 \%$ levels). Concentration at the $3 \%$ level reached $46.2 \%$ in 2010 from $32.5 \%$ in 2000 , and at the $5 \%$ level increased to $37.1 \%$ in 2010 from 25.5\%. These statistics are in line with existing empirical research in the UK such as Mura (2007), Florackis (2008), Florackis and Ozkan (2009) and Ozkan (2011). Likewise, the average number of major shareholders at the firm level displays a steady increase from 3.91 in 2000 to 5.33 in 2010 . When analysing shareholders' portfolio allocations so as to understand shareholders' firm and industry-level investment behaviour, it is found that shareholders tend to diversify their overall portfolio over a number of equities in order to mitigate systematic market risk. In our sample, the total number of industry shareholdings at the firm level is in the range of 18.7 (in 2000) to 24.9 (in 2010). This means that a shareholder in general invests in four or five equities within the same industry. A shareholders' average industry investment percentage is calculated as the average of the shareholders' total industry 
investment value to their overall portfolio value. The average shareholder industry investment percentage is in the range of $53 \%$ to $59 \%$ and an increasing trend exists during the period 2007-2010. Similarly, an increasing trend in the shareholders' average investment percentage is observed for the same period at the firm level. In our observations of the largest shareholders, the ownership level increased from $14.4 \%$ in 2000 to $18.4 \%$ in 2010 . On average, $41 \%$ of the largest shareholders have at least one other investment within the same industry code. The largest shareholders tend to invest $48 \%$ of their overall portfolios in the firms in which they are the largest owner.

\section{(Insert Table 6 about here)}

\subsection{Multivariate analysis}

Our multivariate tests are based on a large unbalanced panel dataset of 6,175 firm-year observations from 2,364 non-financial UK firms over the period 2000-2010 after cleaning the missing data and outliers. Table 7 reports the results of the pooled OLS estimations of our three regression equations (Model 1-3) on the UK data. In particular, Model 1 (the research model) displays the estimated coefficients of the independent variables that capture the impact of the governance role of corporate boards and shareholders on firm performance of the LSElisted firms. Then, Model 2 modifies our research specification by disaggregating the directorlevel variables into two main components to empirically identify the effects of executive and non-executive directors separately. Finally, Model 3 expands Model 2 by adding a dummy variable, which equals 1 if the largest shareholder is an institutional investor and 0 otherwise, in order to better understand the impact of institutional shareholdings on performance in the UK market. We obtain the pooled OLS estimates for all models using White's corrected heteroscedasticity robust regressions and thus our results do not suffer from the problem of heteroscedasticity.

\section{(Insert Table 7 about here)}

The results reveal that Models 1, 2 and 3 are overall statistically significant at the $1 \%$ level $\left(F\right.$-statistics $<0.01$ ) with adjusted $R^{2}$ values of approximately $14 \%$. Using the resourcebased view perspective, we employ external linkages and managerial experience variables to measure the board capabilities. The pooled OLS estimates show that there is a negative impact of external linkages of directors (DRCTRSHIP), measured as average directorship per director, on firm performance (TOBINQ) $(\beta=-0.0848, p<0.10$, Model 1). This inverse correlation is consistent with Non and Franses (2007) who find interlocking directorates have a negative effect on firm performance and is also in accordance with the concerns raised by the Council of Institutional Investors (CII), implying that multiple directorships place a burden on directors and such directors do not exert their monitoring commitments efficiently. Having examined the influences of executive and non-executive directors on performance separately, our results further indicate a strong negative relationship between the average number of directorships per non-executive director (NONEXEDRCTRSHIP) and firm performance $(\beta=$ $-0.0735, p<0.01$, Model 2). This finding is contrary to Ferris et al. (2003) who report no evidence that interlocks prevent independent directors from undertaking their monitoring role accurately but is in line with the agency cost theory and recommendations of the CII (1998), suggesting that multiple directorships require greater commitment and additional time from non-executive directors, which in turn increase the exposure of agency costs and lead to a negative impact on corporate performance. However, our estimates show that this scenario does not hold for executive directors (EXEDRCTRSHIP) as a positive association is observed 
$(\beta=0.175, p<0.10$, Model 2) - consistent with the resource-based view, this indicates the multiple directorships of the executive directors are a value-adding capability to corporate performance. Overall, our evidence therefore provides partial support for $\mathrm{H} 1$, confirming that external linkages of corporate directors (non-executives only) have a negative effect on firm performance in the UK market.

Moreover, we use four proxies for managerial experience; namely, "the same task", "other task", "industry" and "the same firm" experience. The results in Table 7 present that there is no impact of the industry (INDUSTRYEXP) and the same firm experience (SAMEFIRMEXP) variables on performance, whereas both the same task (TASKEXP) and other task (OTHERTASKEXP) experience of corporate directors have a positive and statistically significant effect on the LSE-listed firms' performance $(\beta=0.189, p<0.10$, Model 1 and $\beta=0.325, p<0.01$, Model 1, respectively). These findings are consistent with the resourcebased theory that suggests the managerial experience of corporate directors is an important characteristic in increasing performance. The evidence is also in line with Kroll et al. (2008) who find that directors with knowledge accumulated through managerial experience can be better monitors and advisors to top management. More specifically, the coefficient estimates reported by Model 2 infer that the impacts of the task-based experience (both the same and other tasks) of non-executive directors are positive and significant (NONEXETASKEXP, $\beta=$ $0.147, p<0.05$, Model 2 and NONEXEOTHERTASTEXP, $\beta=0.188, p<0.01$, Model 2 , respectively) but these do not hold for executive directors. This evidence may be attributed to the explanation that independence and experience better allow the board to undertake a supervisory as well as a monitoring role in order to resolve the conflicts of interest through nonexecutives' independent judgement, so thus increase the firm performance. Consequently, our findings lend partial support to $\mathrm{H} 2$ that managerial experience (non-executives only) is positively related to firm performance in the UK.

Regarding the board structure variables, our test results show that board independence (BINDEPENCE) has a consistent positive impact on TOBINQ in all models $(\beta=0.0087$, $p<0.01$, Model $1 ; \beta=0.0107, p<0.01$, Model $2 ; \beta=0.0106, p<0.01$, Model 3 ). This might mean that independent directors exert a monitoring and controlling function on behalf of shareholders to limit managerial opportunistic behaviour and hence increase firm performance. However, the results detect no significant influence of board size (BOARDSIZE) and CEO/chairman duality (DUAL) on firm performance. Similarly, in the context of board incentives, no evidence of the impact of directorial ownership (DIROWN) is found, nor does evidence exist to support a quadratic association between directorial ownership (DIROWN ${ }^{2}$ ) and Tobin's $Q$ at an aggregate level. Contrarily, once Model 2 disaggregates the directorial ownership into two components, it is observed that executive ownership (EXEOWN) has an inverse U-shaped relationship. Specifically, the sign of the link is positive at lower levels of ownership $(\beta=0.0141$, $p<0.01$, Model 2), consistent with the convergence of interest hypothesis, indicating that executive officers' interests are aligned at lower levels of equity holdings. Whereas the impact is negative at higher levels $\left(\mathrm{EXEOWN}^{2}, \beta=-0.000201, p<0.01\right.$, Model 2$)$ - thus supports the managerial entrenchment hypothesis, revealing that the executive ownership-performance association turns into a significant negative impact due to managers becoming entrenched. Lastly, our another directorial incentive variable, namely executive director's pay (REMUNERATION), has a large positive effect on firm performance throughout Models 1-3 ( $\beta$ $=0.745, p<0.01$, Model $1 ; \beta=0.755, p<0.01$, Model $2 ; \beta=0.757, p<0.01$, Model 3$)$. This is consistent with Ozkan (2011) who reports a positive association between CEO's cash compensation and shareholder returns in the UK market. 
Furthermore, the results display that ownership concentration (OWNCON) has a highly significant negative impact on firm performance $(\beta=-0.00261, p<0.01$, Model 1 and $\beta=$ $-0.00246, p<0.01$, Model 2). This finding suggests the inefficiency of having ownership concentration as a widely used proxy for shareholders' commitment to monitoring. In fact, the negative association might be due to underlying portfolio allocations of large shareholders that are not aligned to the corresponding ownership percentages. In other words, the impact of an individual shareholding might be more or less than its corresponding impact in the shareholders' overall portfolio. As well, Model 3 takes the effect of institutional shareholdings (LRGSTSHRHLDR) into account and indicates that institutional investors have a significant negative impact on firm performance $(\beta=-0.0635, p<0.05$, Model 3$)$ in addition to similar results reported previously. This evidence is accordance with Zechauser and Pound (1990) who argue that institutional shareholders are in general passive and do not proactively engage with the investee firms in corporate matters to improve firm performance. Given that institutional investors hold large stakes in the UK equity market, our evidence implies that the governance role expected of them is a topic of debate.

However, we measure the shareholders' capability as the total number of industry shareholdings of major shareholders (SHRINTERLOCKS) and our results reveal a significant positive impact of shareholder capability on the firm's performance $(\beta=0.0474, p<0.01$, Model 1) - similarly, the estimates of Model 2 and Model 3 report highly significant positive coefficients on SHRINTERLOCKS. This positive effect is in line with the resource-based theory, suggesting that interlocking large shareholders not only bring capital to investee companies but can also supply industry knowledge, experience and resources, and thus help improve firm performance. This finding may also suggest that, by accumulating industryspecific knowledge, major investors mitigate the information asymmetry problem and utilise the efficient industry-specific governance mechanisms (e.g., adopting optimal levels of R\&D, implementing better performance-based compensation structures and accessing the insight information in investee firms). As hypothesised, our evidence indicates that major shareholders do not have only a monitoring role but also contribute to improving the LSE firm's financial performance through their industry-specific knowledge, and therefore provides support for $\mathrm{H} 3$.

Based on the agency-cost-explanation framework, we measure the shareholder's incentive to have an impact on performance by the lock-in effect of the largest shareholder (SHRLOCKING) that is the ratio of the firm-level investment value of such investors to their total portfolio value. Our estimates in Table 7 show a significant positive impact of the lock-in effect on the LSE-listed firm's performance $(\beta=0.0665, p<0.10$, Model 1 and $\beta=0.0664$, $p<0.10$, Model 2). Although we find a negative impact of ownership concentration and institutional shareholdings on firm performance alone, this evidence reveals that the marginal impact of individual stock returns on the shareholders' overall portfolio demonstrates a positive association. This means that major shareholders, typically institutional investors, in the UK market become active monitors and deploy the necessary control tools and processes in the system once their dependence on individual investee firms affects their overall portfolio profitability. It explains that although index tracking and portfolio diversification have a number of advantages in investment, they do not encourage shareholders towards monitoring the management, but the lock-in effect does. Accordingly, this finding is consistent with the incentive dimension of the agency theory, suggesting that the portfolio-shareholding investment ratio of the largest shareholder has a positive effect on firm performance. Therefore, this finding provides support for $\mathrm{H} 4$. 


\subsection{Robustness checks}

We compute supplementary tests to check the robustness of our main findings by utilising principal component analysis (PCA) and employing alternative specifications of the model. We first attempt to combine our various board capability (i.e., external linkages and managerial experience) variables into a single board capability proxy (BRDCAPABILITY) using PCA in Model 4 - this econometric approach has been employed in other settings for data combination by previous studies (e.g., Callahan et al., 2003; Florackis and Ozkan, 2009). One advantage of this approach is that PCA allows us to determine the overall impact of the board of the directors' capability on firm performance, rather than using a set of different variables. More importantly, it helps control for the possible multicollinearity problem that may arise from including several board capability measures independently in the research model. Although we detect no serious multicollinearity concerns between our independent variables when calculating Pearson's correlations and variance inflation factor (VIF) values, there seem to be correlations exist among the individual board capability variables. In this respect, utilising PCA reduces multidimensional data with various measures towards a new single component and therefore enables us to effectively control for potential interrelations between board capability variables. Then, we construct two different principal components related to the executive (EXECAPABILITY) and non-executive (NONEXECAPABILITY) directors in Model 5 to separately ascertain the impact of their overall associated capabilities on performance.

Next, we consider additional control variables to check whether our main results are sensitive to the usage of alternative model specifications. Particularly, we expand Model 5 by introducing each of the different measures alone to capture the effect of financial policies on firm performance and so to control for these effects in our model. These measures include capital structure decisions, such as long-term (LEVERAGE) and short-term debt policies (SHORTDEBT), and dividend policy (DPAYOUT) in Models 6, 7 and 8, respectively. Table 8 shows the estimation results of our further tests (Model 4-8) and reveals that the results are consistent with what we report previously, because the independent variables have the same directional signs and exhibit similar statistical significance behaviour. Consequently, this evidence confirms the robustness of our main findings.

(Insert Table 8 about here)

\section{Concluding Remarks}

We examine the governance role of shareholders and board of directors on firm performance by providing an eclectic multi-theoretic framework. This study is important because it extends the existing agency-based research that solely relies on monitoring of the management by including incentive focus of the agency theory as well as incorporating the resource-based view on both shareholders and corporate directors. Hence, it integrates these two dominant theories for a better insight into the governance-performance association and attempts to improve the partial explanations supplied by single-theory studies. Accordingly, using a large panel dataset of publicly-listed 2,364 non-financial UK firms over the period 2000-2010, the findings of our study lead to several important conclusions.

First, our results reveal that shareholders' capability, as measured by the total number of industry shareholdings, has a large significant impact on firm performance. This positive effect suggests that cross-company ownership or interlocking shareholders within the same industry contribute to the investee firm's business beneficially through a set of different channels. These might include providing trustworthy and reliable information, introducing best 
business practices and processes, and bringing in critical industry resources. Second, we argue that ownership concentration alone cannot reliably measure shareholders' commitment (incentive) to monitor the management as it does not explicitly maximise the benefits of shareholders' monitoring. To determine the effectiveness of the monitoring role of shareholders, we therefore investigate the incentives for shareholders to be effective monitors through their underlying portfolio allocations. Having employed the lock-in-effect of the largest shareholder to measure such a shareholder's incentive, the results show that shareholders have a positive impact on the firm's performance when their dependencies are higher than in regard to the stock in which they have a more marginal dependence.

Moreover, our results provide evidence that indicates the underlying capabilities of the board of directors and their impact on corporate performance. More specifically, the evidence shows that the linkages of executive directors to the external environment have a positive impact on firm performance, but those of non-executives have a negative impact. This supports the argument raised by the Council of Institutional Investors that having multiple directorships creates concerns related to the non-executive directors' commitment and consequently detrimentally affects their performance. Finally, the empirical results further detect that the managerial experience of corporate directors is statistically an important factor in determining firm performance. In particular, we find that the monitoring experience of non-executive directors has a positive impact on performance but no evidence reported to prove the impact of executive directors' previous directorship experience. Nor does industry experience or same-firm experience on the part of directors have an impact on firm performance.

Overall, our study improves theoretical understanding about the governanceperformance relationship by suggesting that one needs to consider various factors such as structure, incentive and capability aspects of shareholders and corporate directors focusing both the agency theory and resource-based view perspective, rather than adopting a singleexplanation-based approach or examining the effect of different corporate governance mechanisms separately. Furthermore, our study has various practical implications. Especially, the findings provide more insights into capability dimension of shareholders and the role of incentives in motivating shareholders to exercise stronger oversight on the management rather than just using ownership concentration. Hence, it can be a valuable guidance for investors, corporate managers and policymakers.

Our study has certain limitations. First, the period covered in this study (2000-2010) is not recent. However, governance and ownership structures reported are not drastically changing but found to be relatively stable over time, thus our results provide invaluable insight in the UK context and may be generalizable to the more recent time periods. On the other hand, the current COVID-19 pandemic has created a global crisis that caused severe impacts not only on the health and social lives of people but also on global economies and all kinds of businesses across the world. Therefore, we call for future studies to examine the impact of the COVID-19 crisis on the governance role of shareholders and corporate directors in the UK. Hence, our study can serve as a benchmark for such studies to identify similarities and differences pre and post the coronavirus pandemic. Second, our study only focuses on the UK firms and presents empirical evidence from the developed UK market. In this respect, we encourage researchers to conduct future studies from other developed and emerging markets using our integrated model but, of course, with uniquely reflecting the characteristics of the market(s) investigated. This could help detect similarities and differences on the association between corporate governance and firm performance across different countries, and thus enabling us to generalize the findings. 


\section{References}

Abu Khadra, H. and Delen, D. (2020). 'Nonprofit organization fraud reporting: does governance matter?', International Journal of Accounting and Information Management, 28(3), pp. 409-428.

Alchian, A. A. and S. Demsetz (1972). 'Production, information costs and economic organization', American Economic Review, 62, pp. 777-795.

AlHares, A., Elamer, A. A., Alshbili, I. and M. W. Moustafa (2020). 'Board structure and corporate R\&D intensity: evidence from Forbes global 2000', International Journal of Accounting and Information Management, 28(3), pp. 445-463.

Al-Najjar, B. and Kilincarslan, E. (2016). 'The effect of ownership structure on dividend policy: evidence from Turkey', Corporate Governance, 16(1), pp. 135-161.

Asimakopoulos, J. (2009). 'Globally segmented labor markets: the coming of the greatest boom and bust, without the boom', Critical Sociology, 35, pp. 175-198.

Baber, W. R., S. N. Janakiraman and S. Kang (1996). 'Investment opportunities and the structure of executive compensation', Journal of Accounting and Economics, 21, pp. 297-318.

Barney, J. B. (1986). 'Strategic factor markets: expectations, luck, and business strategy', Management Science, 32, pp. 1231-1241.

Bazerman, M. H. and F. D. Schoorman (1983). 'A limited rationality model of interlocking directorates', Academy of Management Review, 8, pp. 206-217.

Berle, A. and G. Means (1932). The Modern Corporation and Private Property. New York: Macmillan.

Bertoni, F. and P. A. Randone (2006). The small world of Italian finance: ownership interconnections and board interlocks amongst Italian listed companies. Working Paper. Available online at: https://papers.ssrn.com/sol3/papers.cfm?abstract id=917587

Bhagat, S. and B. Black (1999). 'The uncertain relationship between board composition and firm performance', Business Lawyer, 54, pp. 921-963.

Bishop, S. R., R. C. Harvey, W. F. Robert and J. T. Garry (2000). Corporate Finance. Sydney: Prentice Hall.

Bowman, S.R. (2009). The Modern Corporation and American Political Thought: Law, Power, and Ideology. Pennsylvania: The Pennsylvania State University Press.

Brancato, C. K. (1997). Institutional investors and corporate governance. Chicago: McGraw Hill.

Brickley, J. A., J. L. Coles and G. Jarrell (1997). 'Leadership structure: separating the CEO and chairman of the board', Journal of Corporate Finance, 3, pp. 189-220.

Brown, L. D. and M. L. Caylor (2006). 'Corporate governance and firm valuation', Journal of Accounting and Public Policy, 25, pp. 409-434.

Burt, R. S. (1980). 'Cooptive corporate actor networks: a reconsideration of interlocking directorates involving American manufacturing', Administrative Science Quarterly, 25, pp. 557-582.

Cadbury, A. (1992). Report of the Committee on the Financial aspects of Corporate Governance. London: Gee Publishing Ltd.

Callahan, W. T., J. A. Millar and C. Schulman (2003) 'An analysis of the effect of management participation in director selection on the long-term performance of the firm', Journal of Corporate Finance, 9, pp. 169-81.

Chang, R., Y. Chang, C. Chang and F. Hu (2008). 'The effects of corporate governance mechanisms and investment opportunity set on firm performance', Corporate Ownership and Control, 5, pp. 135-148.

Chen, J., D. Chen and P. He (2008). 'Corporate governance, control type, and performance: the New Zealand Story', Corporate Governance and Control, 5, pp. 24-35.

Chuang, C. and A. Wu (2011). The impact of social capital from large shareholders on firm performance: an emerging country tests. AAA 2012 Management Accounting Section (MAS) Meeting Paper. Available online at: https://ssrn.com/absract=1907505

Council of Institutional Investor (CII) (1998). Core Policies, Positions and Explanatory Notes. Washington DC: Council of Institutional Investors. 
Cole, R. A. and H. Mehran (1998). 'The effect of changes in ownership structure on performance: evidence from the thrift industry', Journal of Financial Economics, 50, pp. 291317.

Conyon, M. J. and S. I. Peck (1998). 'Board control, remuneration committees and top management compensation', Academy of Management Journal, 41, pp. 146-157.

Cotter, J. and M. Silvester (2003). 'Board and monitoring committee independence', Abacus, 39, pp. 211-232.

Cropanzano, R. and M. S. Mitchell (2005). 'Social exchange theory: an interdisciplinary review', Journal of Management, 31, pp. 874-900.

Dalton, D. R., C. M. Daily, A. E. Ellstrand and J. L. Johnson (1998). 'Meta-analytic reviews of board composition, leadership structure, and financial performance', Strategic Management Journal, 19, pp. 269-290.

Darrough, M. N. and N. M. Stoughton (1986). 'Moral hazard and adverse selection: the question of financial structure', Journal of Finance, 41, pp. 501-513.

Davies, J. R., D. Hillier and P. McColgan (2005). 'Ownership structure, managerial behaviour and corporate value', Journal of Corporate Finance, 11, pp. 645-660.

De Miguel, A., J. Pindado and C. Torre (2004). 'Ownership structure and firm value: new evidence from Spain', Strategic Management Journal, 25, pp. 1199-1207.

De Miguel, A., J. Pindado and C. Torre (2005). 'How do entrenchment and expropriation phenomena affect control mechanisms?', Corporate Governance, 13, pp.505-516.

Demsetz, H. and K. Lehn (1985). 'The structure of corporate ownership: causes and consequences', Journal of Political Economy, 93, pp. 1155-1177.

Demsetz, H. and B. Villalonga (2001). 'Ownership structure and corporate performance', Journal of Corporate Finance, 7, pp. 209-233.

Dierickx, I. and K. Cool (1989). 'Asset stock accumulation and sustainability of competitive advantage', Management Science, 35, pp. 1504-1511.

Dong, M. and Ozkan, A. (2008). 'Institutional investors and director pay: an empirical study of UK companies', Journal of Multinational Financial Management, 18(1), pp. 16-29.

Douma, S., R. George and R. Kabir (2006). 'Foreign and domestic ownership, business groups, and firm performance: evidence from a large emerging market', Strategic Management Journal, 27, pp. 637-657.

Eisenberg, T., S. Sundgren and M. T. Wells (1998). 'Large board size and decreasing firm value in small firms', Journal of Financial Economics, 48, pp. 35-54.

Eisenhardt, K. M. (1989). 'Agency theory: an assessment and review', Academy of Management Review, 14, pp. 57-74.

Elmagrhi, M. H., Ntim, C. G., Crossley, R. M., Malagila, J. K., Fosu, S. and Vu, T. V. (2017) 'Corporate governance and dividend pay-out policy in UK listed SMEs: the effects of corporate board characteristics', International Journal of Accounting and Information Management, 25(4), pp. 459-483.

Fama, E. F. and M. C. Jensen (1983). 'Separation of ownership and control', Journal of Law and Economics, 26, pp. 301-325.

Ferris, S. P., M. Jagannathan and A. C. Pritchard (2003). 'Too busy to mind the business? Monitoring by directors with multiple board appointments', Journal of Finance, 58, pp. 10871111.

Field, L. C. and A. Mkrtchyan (2017). 'The effect of director expertise on acquisition performance', Journal of Financial Economics, 123, pp. 488-511.

Filatotchev, I., R. Kapelyushnikov, N. Dyomina and S. Aukutsionek (2001). 'The effects of ownership concentration on investment and performance in privatized firms in Russia', Managerial and Decision Economics, 22, pp. 299-313.

Florackis, C. (2005). 'Internal corporate governance mechanisms and corporate performance: evidence for UK firms', Applied Financial Economics Letters, 1, pp. 211-216.

Florackis, C. (2008). 'Agency costs and corporate governance mechanisms: evidence for UK firms', International Journal of Managerial finance, 4, pp. 37-59.

Florackis, C. and A. Ozkan (2009). 'Managerial incentives and corporate leverage: evidence from the United Kingdom', Accounting and Finance, 49, pp. 531-553. 
Forbes, D. P. and F. J. Milliken (1999). 'Cognition and corporate governance: understanding boards of directors as strategic decision making groups', Academy of Management Review, 24, pp. 489-505.

Galaskiewicz, J. and S. Wasserman (1989). 'Mimetic processes within an interorganisational field: an empirical test', Administrative Science Quarterly, 34, pp. 454-479.

Geletkanycz, M. A. and D. C. Hambrick (1997). 'The external ties of top executives: implications for strategic choice and performance', Administrative Science Quarterly, 42, pp. 654-681.

Gillan, S. L. and L. T. Starks (2003). 'Corporate governance, corporate ownership, and the role of institutional investors: a global perspective', Journal of Applied Finance, 13, pp.422.

Goergen, M. and L. Renneboog (2011). 'Managerial compensation', Journal of Corporate Finance, 17, pp. 1068-1077.

Gompers, P., J. Ishii and A. Metrick (2003). 'Corporate governance and equity prices', Quarterly Journal of Economics, 118, pp. 107-155.

Granovetter, M. (1985). 'Economic action and social structure: the problem of embeddedness', American Journal of Sociology, 91, pp. 481-510.

Gregg, P., S. Jewell and I. Tonks (2010). Executive pay and performance in the UK. London School of Economics, Financial Markets Group (FMG), Discussion Paper No 657.

Grossman, S. J. and O. D. Hart (1980). 'Takeover bids, the free-rider problem, and the theory of the corporation', Bell Journal of Economics, 11, pp. 42-64.

Guest, P. M. (2009). 'The impact of board size on firm performance: evidence from the UK', European Journal of Finance, 15, pp. 385-404.

Hambrick, D.C. and P. A. Mason (1984). 'Upper echelons: the organisation as a reflection of its top managers', Academy of Management Review, 9, pp.193-206.

Hartzell, J. C. and L. T. Starks (2003). 'Institutional investors and executive compensation', Journal of Finance, 58, pp. 2351-2374.

Haunschild, P. R. and C. M. Beckman (1998). 'When do interlocks matter? Alternate sources of information and interlock influence', Administrative Science Quarterly, 43, pp. 815844.

Hermalin, B. E. and M. S. Weisbach (1991). 'The effects of board composition and direct incentives on firm performance', Financial Management, 20, pp. 101-112.

Hillman, A. J. and T. Dalziel (2003). 'Boards of directors and firm performance: integrating agency and resource dependence perspectives', Academy of Management Review, 28, pp. 383-396.

Jackling, B. and S. Johl (2009). 'Board structure and firm performance: evidence from India's top companies', Corporate Governance, 17, pp. 492-509.

Jensen, M. C. and W. H. Meckling (1976). 'The theory of the firm: managerial behavior agency costs and ownership structure', Journal of Financial Economics, 3, pp. 305-360.

Jensen, M. C. and K. J. Murphy (1990). 'Performance pay and top management incentives', Journal of Political Economy, 98, pp. 225-264.

Ji, X., Ahmed, K. and Lu, W. (2015). 'The impact of corporate governance and ownership structure reforms on earnings quality in China', International Journal of Accounting and Information Management, 23(2), pp. 169-198.

Johnston, J. (2002). 'Tenure, promotion and executive remuneration', Applied Economics, 34, pp. 993-997.

Kahn, C. and A. Winton (1998). 'Ownership structure, speculation, and shareholder intervention', Journal of Finance, 53, pp. 99-129.

Khan, R., R. Dharwadkar and P. Brandes (2005). 'Institutional ownership and CEO compensation: a longitudinal examination', Journal of Business Research, 58, pp. 1078-1088.

Karim, A. K. M. W., van Zijl, T. and S. Mollah (2013). 'Impact of board ownership, CEOChair duality and foreign equity participation on auditor quality choice of IPO companies: evidence from an emerging market', International Journal of Accounting and Information Management, 21(2), pp. 148-169.

Kesner, I. F. (1989). 'Shareholders and the issue of corporate governance: the silenced partner', Business Horizons, 32, pp. 16-21. 
Khosa, A. (2017). 'Independent directors and firm value of group-affiliated firms', International Journal of Accounting and Information Management, 25(2), pp. 217-236.

Kilincarslan, E, Elmagrhi, M. H. and Li, Z. (2020). 'Impact of governance structures on environmental disclosures in the Middle East and Africa', Corporate Governance, 20(4), pp. 739-763.

Kilincarslan. E and Ozdemir, O. (2018). 'Institutional investment horizon and dividend policy: an empirical study of UK firms', Finance Research Letters, 24, pp. 291-300.

Klein, A. (1998). 'Firm performance and board committee structure', Journal of Law and Economics, 41, pp. 275-304.

Ko, C., Lee, P. and A. Anandarajan (2019). 'The impact of operational risk incidents and moderating influence of corporate governance on credit risk and firm performance', International Journal of Accounting and Information Management, 27(1), pp. 96-110.

Kroll, M., B. A. Walters, and P. Wright (2008). 'Board vigilance, director experience, and corporate outcome', Strategic Management Journal, 29, pp. 363-382.

Lin, C., Y. Ma and D. Su (2009). 'Corporate governance and firm efficiency: evidence from China's publicly listed firms', Managerial and Decision Economics, 30, pp. 193-209.

Lskavyan, V. and M. Spatareanu (2006). 'Ownership concentration, market monitoring and performance: evidence from the UK, the Czech Republic and Poland', Journal of Applied Economics, 9, pp. 91-104.

Mahoney, J. T. and J. R. Pandian (1992). 'The resource-based view within the conversation of strategic management', Strategic Management Journal, 13, pp. 363-380.

Mangena, M., V. Tauringana and E. Chamisa (2012). 'Corporate boards, ownership structure and firm performance in an environment of severe political and economic crisis', British Journal of Management, 23, pp. S23-S41.

Markowitz, H. (1952). 'Portfolio Selection', Journal of Finance, 7, pp. 77-91.

Maug, E. (1998). 'Large shareholders as monitors: is there a trade-off between liquidity and control?', Journal of Finance, 53, pp. 65-98.

McConnell, J. J. and H. Servaes (1990). 'Additional evidence on equity ownership and corporate value', Journal of Financial Economics, 27, pp. 595-612.

Mura, R. (2007). 'Firm performance: do non-executive directors have minds of their own? Evidence from UK panel data', Financial Management, 36, pp. 81-112.

Nicholson, G. J. and G. C. Kiel (2007). 'Can directors impact performance? A case-based test of three theories of corporate governance', Corporate Governance, 15, pp. 585-608.

Non, M. and P. H. Franses (2007). Interlocking boards and firm performance: evidence from a new panel database, Tinbergen Institute, Discussion Paper No 07-034/2.

North, D. C. (1990). Institutions, institutional change and economic performance. Cambridge: Cambridge University press.

OECD (2011). The role of institutional investors in promoting good corporate governance, Corporate Governance, Organisation for Economic Co-operation and Development, OECD Publishing.

Ozkan, N. (2011). 'CEO compensation and firm performance: an empirical investigation of UK panel data', European Financial Management, 17, pp.260-285.

Page, F. H. (1991). 'Optimal contract mechanisms for principal-agent problems with moral hazard and adverse selection', Economic Theory, 1, pp. 323-338.

Parkinson, J. E. (2002). Corporate power and responsibility: issues in the theory of company law. Oxford: Clarendon Press.

Peni, E. and V. Sami (2012). 'Did good corporate governance improve bank performance during the financial crisis?', Journal of Financial Services Research, 41, pp. 19-35.

Perrow, C. Y. (1988). Complex organisations: a critical essay, 3rd edn. New York: Random House.

Peteraf, M. A. (1993). 'The cornerstones of competitive advantage: a resource-based view', Strategic Management Journal, 14, pp. 179-191.

Pfeffer, J. and G. R. Salancik (1978). The external control of the organisations, A resource dependence perspective. California: Stanford University Press.

Rao, H., G. F. Davis and A. Ward (2000). 'Social identity and mobility: why firm leave the NASDAQ and join the New York Stock Exchange', Administrative Science Quarterly, 45, pp. 268-292.. 
Richardson, G. B. (1972). 'The organisation of industry', Economic Journal, 82, pp. 883896.

Salinger, L. M. (2005). Encyclopaedia of White-Collar \& Corporate Crime. California: Sage Publications, Inc.

Shleifer, A. and R. W. Vishny (1986). 'Large shareholders and corporate control', Journal of Political Economy, 94, pp. 461-488.

Shleifer, A. and R. W. Vishny (1997). 'A survey of corporate governance', Journal of Finance, 52, pp. 737-783.

Short, H. and K. Keasey (1999). 'Managerial ownership and the performance of firms: evidence from the UK', Journal of Corporate Finance, 5, pp. 79-101.

Shropshire, C. (2010). 'The role of the Interlocking director and board receptivity in the diffusion of practices', Academy of Management Review, 35, pp. 246-264.

Siddiqui, S. S. (2015). 'The association between corporate governance and firm performance - a meta-analysis', International Journal of Accounting and Information Management, 23(3), pp. 218-237.

Singh, S., N. Tabassum, T. K. Darwish and G. Batsakis (2018). 'Corporate governance and Tobin's $Q$ as a measure of organisational performance', British Journal of Management, 29, pp. 171-190.

Stewardship Code (2010). The UK Stewardship Code. London: Financial Reporting Council.

Stuart, T. E. and S. Yim (2010). 'Board interlocks and the propensity to be targeted in private equity transactions', Journal of Financial Economics, 97, pp. 174-189.

Thomsen, S. and T. Pedersen (2000). 'Ownership structure and economic performance in the largest European countries', Strategic Management Journal, 21, pp. 689-705.

Ullah, M. S., Muttakin, M. B. and A. Khan (2019). 'Corporate governance and corporate social responsibility disclosures in insurance companies', International Journal of Accounting and Information Management, 27(2), pp. 284-300.

Vafeas, N. and E. Theodorou (1998). 'The relationship between board structure and firm performance in the UK', British Accounting Review, 30, pp. 383-407.

Wahal, S. (1996). 'Pension fund activism and firm performance', Journal of Financial and Quantitative Analysis, 31, pp. 1-24.

Ward, K. (1993). Corporate Financial Strategy. Oxford: Butterworth-Heinemann.

Weir, C. and D. Laing (2003). 'Ownership structure, board composition and the market for corporate control in the UK: an empirical analysis', Applied Economics, 35, pp. 1747-1759.

Wright, P., S. P. Ferris, A. Sarin and V. Awasthi (1996). 'Impact of corporate insider, blockholder and institutional equity ownership on firm risk taking', Academy of Management Journal, 39, pp. 441-463.

Yermack, D. (1996). 'Higher market valuation of companies with a small board of directors', Journal of Financial Economics, 40, pp. 185-211.

$\mathrm{Yu}, \mathrm{M}$. and Y. Wang (2018). 'Firm-specific corporate governance and analysts' earnings forecast characteristics: evidence from Asian stock markets', International Journal of Accounting and Information Management, 26(3), pp. 335-361.

Zahra, S. A. and J. A. Pearce (1989). 'Boards of directors and corporate financial performance: a review and integrative model', Journal of Management, 15, pp. 291-334.

Zeckhauser, R. J. and J. Pound (1990). 'Are large shareholders effective monitors? An investigation of share ownership and corporate performance', Asymmetric Information, Corporate Finance, and Investment. University of Chicago Press: Chicago.

Zwiebel, J. (1995). 'Block investment and partial benefits of corporate control', Review of Economic Studies, 62, pp. 161-185. 
Table 1. Summary of agency-based governance-performance research

Corporate governance mechanism Existing agency-based corporate governance-performance research and findings

Ownership concentration

Lin et al. (2009) - U-shaped relation between ownership concentration and firm performance indicating tunnelling activities by the largest shareholder.

Chen et al. (2008) - positive correlation between diffused shareholder structure and firm performance that allows managers to raise agency costs

Chang et al. (2008) - negative correlation between institutional ownership and firm performance is stronger for firms with higher investment opportunities

Mura (2007) - negative relation between institutional and non-institutional ownership concentration and firm performance.

Douma et al. (2006) - positive correlation between foreign institutional ownership and performance.

Florackis (2005) - no correlation between ownership concentration measured at $3 \%$ level and firm performance measured by Tobin's $Q$.

De Miguel et al. (2004) - positive correlation with firm value at low levels, negative at high levels.

Thomsen and Pedersen (2000) - positive correlation in particular for large owners such as banks and institutional shareholders, which have a significant positive impact on firms' performance

Filatotchev et al. (2001) - negative correlation between ownership concentration and firm's investment and performance.

McConnell and Servaes (1990) - positive association between institutional investors' shareholder concentration and firm performance.

Guest (2009) - negative association between board size and firm performance using a large data set covering 1981 to 2002 in the UK.

Brown and Caylor (2006) - positive association between well-known board composition measures and firm accounting and market performance.

Eisenberg et al. (1998) - negative association between board size and profitability in a sample of small and mid-size firms.

Dalton et al. (1998) - medium effect moderated by firm size using a meta-analysis of 54 empirical studies, and in general little evidence to support the systematic governance and financial performance association.

Yermack (1996) - inverse association between board size and market valuation measured by Tobin's $Q$ controlling for size and industry.

Board independence

Cotter and Silvester (2003) - no significant association.

Bhagat and Black (1999) - negative association between board independence and firm performance; in fact, a positive association between low levels of independence and higher firm performance.

Vafeas and Theodorou (1998) - no clear link between board composition including board independence and firm performance, robust to alternative specifications of the model.

Dalton et al. (1998) and Klein (1998) - no statistical support for an association between board composition and financial performance.

CEO/chairman duality

Florackis (2008) - no association between Chairman/CEO duality and firm performance using a large sample of listed firms on London Stock Exchange over the period 1999-2003.

Weir and Laing (2003) - companies that do not have duality are more likely to be acquired.

Brickley et al. (1997) - positive association between Chairman/CEO duality, however separation also introduces additional costs. 
De Miguel et al. (2004) - positive correlation with firm value at low and high levels, negative at intermediate levels.

Demsetz and Villalonga (2001) - managerial equity ownership and firm performance are unrelated.

Cole and Mehran (1998), De Miguel et al. (2005), Florackis (2008), Wright et al. (1996) - positive association. Himmelberg et al. (1999) - managerial ownership and firm performance are endogenously determined using a large panel data set.

McConnell and Servaes (1990) - curvilinear relation between managerial ownership at $40-50 \%$ level and firm performance.

Short and Keasey (1999) and Hermalin and Weisbach (1991) - non-linear relationship between firm performance and managerial ownership supporting both alignment hypothesis at low levels of managerial ownership and entrenchment hypothesis at higher levels.

Remuneration

Ozkan (2011) - a significant positive association between shareholder returns and CEO's cash compensation.

Khan et al. (2005) - negative association between the largest owner concentration and lower levels of compensation.

Hartzell and Starks (2003) - a positive link between Herfindahl index of institutional ownership concentration and pay-for-performance sensitivity of executive compensation.

Johnston (2002) - positive association between job tenure and promotions and high levels of pay within the top 500 companies.

Conyon and Peck (1998) - limited impact of board monitoring, presence of remuneration committee and CEO/chairman duality on top management pay over the period 1991-1994 in the UK. Baber et al. (1996) - top management incentives have greater sensitivity to market-based performance measures than accounting-based measures.

Jensen and Murphy (1990) - CEOs in large firms have lower compensation levels than CEOs in smaller firms 
Table 2. Research variables

\begin{tabular}{|c|c|c|}
\hline Variable & Abbreviation & Definition \\
\hline \multicolumn{3}{|l|}{ Dependent variable } \\
\hline Tobin's Q & TOBINQ & $\begin{array}{l}\text { Ratio of book value of total assets minus the book value of equity plus the market value of equity to book } \\
\text { value of total asset. }\end{array}$ \\
\hline \multicolumn{3}{|l|}{ Independent variables } \\
\hline \multicolumn{3}{|l|}{ Board structure } \\
\hline Board size & BOARDSIZE & Total number of executive and non-executive directors on the board (in logarithm). \\
\hline Board independence & BINDEPENCE & Fraction of non-executive directors to board size. \\
\hline CEO/chairman duality & DUAL & A dummy variable that equals 1 if $\mathrm{CEO}$ and chairman are different people, and 0 otherwise. \\
\hline \multicolumn{3}{|l|}{ Board capability } \\
\hline Multiple directorships per director & DRCTRSHIP & The ratio of total directorships held by corporate directors to total number of directors on the board. \\
\hline Multiple directorships per executive & EXEDRCTRSHIP & The ratio of total directorships held by executives to total number of executive directors. \\
\hline Multiple directorships per non-executive & NONEXEDRCTRSHIP & The ratio of total directorships held by non-executives to total number of non-executive directors. \\
\hline The same task experience of the director & TASKEXP & Average number of directors with the same task experience. \\
\hline The same task experience of the executive & EXETASKEXP & Average number of executives with executive directorship experience. \\
\hline The same task experience of the non-executive & NONEXETASKEXP & Average number of non-executives with non-executive directorship experience. \\
\hline Other task experience of the director & OTHERTASKEXP & Average number of directors with different task experience. \\
\hline Other task experience of the executive & EXEOTHERTASKEXP & Average number of executives with non-executive directorship experience. \\
\hline Other task experience of the non-executive & NONEXEOTHERTASKEXP & Average number of non-executives with executive directorship experience. \\
\hline Industry experience of the director & INDUSTRYEXP & Average number of directors with industry experience. \\
\hline Industry experience of the executive & EXEINDUSTRYEXP & Average number of executives with industry experience. \\
\hline Industry experience of the non-executive & NONEXEINDUSTRYEXP & Average number of non-executives with industry experience. \\
\hline The director's board experience in the same firm & SAMEFIRMEXP & Average number of directors with the same firm experience. \\
\hline The executive's board experience in the same firm & EXESAMEFIRMEXP & Average number of executives with the same firm experience. \\
\hline The non-executive's board experience in the same firms & NONEXESAMEFIRMEXP & Average number of non-executives with the same firm experience. \\
\hline Principal component for board capability & BRDCAPABILITY & $\begin{array}{l}\text { A composite measure that gives a single score for board capability, combining five variables (DRCTRSHIP, } \\
\text { TASKEXP, OTHERTASKEXP, INDUSTRYEXP and SAMEFIRMEXP), after using principal component } \\
\text { analysis. }\end{array}$ \\
\hline Principal component for executive capability & EXECAPABILITY & $\begin{array}{l}\text { A composite measure that gives a single score for executive directors' capability, combining five variables } \\
\text { (EXEDRCTRSHIP, EXETASKEXP, EXEOTHERTASKEXP, } \\
\text { EXESAMEFIRMEXP), after using principal component analysis. }\end{array}$ \\
\hline
\end{tabular}




\section{Principal component for non-executive capability}

Board incentives

Directorial ownership

Directorial ownership squared

Executive ownership

Non-executive ownership

Executive ownership squared

Executive director pay

Shareholder structure

Ownership concentration

Largest shareholder identity

Shareholder capability

Shareholders' total number of industry shareholdings

\section{Shareholder incentives}

Locking ratio (lock-in)

\section{Control variables}

Firm size

Debt policy

Short-term debt

Dividend payout ratio

Industry effect

Year effect
NONEXECAPABILITY

DIROWN

DIROWN $^{2}$

EXEOWN

NONEXEOWN

EXEOWN $^{2}$

REMUNERATION

OWNCON

LRGSTSHRHLDR

SHRINTERLOCKS

SHRLOCKING

FIRMSIZE

LEVERAGE

SHORTDEBT

DPAYOUT

INDUSTRY

YEAR
A composite measure that gives a single score for non-executive directors' capability, combining five variables (NONEXEDRCTRSHIP, NONEXETASKEXP, NONEXEOTHERTASKEXP, NONEXEINDUSTRYEXP and NONEXESAMEFIRMEXP), after using principal component analysis.

Percentage of total common stock ownership held by directors on the board.

A square term for directorial ownership.

Percentage of total common stock ownership held by executive directors.

Percentage of total common stock ownership held by non-executive directors.

A square term for executive ownership.

Retail price index (RPI)-adjusted annualised cash remuneration paid to executive directors (in logarithm).

Percentage of total common stock ownership of shareholders who hold more than $3 \%$ threshold level.

A dummy variable that equals 1 if the largest shareholder is an institutional investor and 0 otherwise.

Total number of major shareholders' industry shareholdings using the ICB codes.

Ratio of the investment value of the largest shareholder to its total portfolio.

Retail price index (RPI)-adjusted annualised sales (in logarithm).

Fraction of total debt to total assets.

Fraction of short-term debt to total assets.

Ratio of total cash dividends paid to total assets.

A vector of dummy variables representing 15 different industry classifications based on ICB codes.

Yearly dummies for the year between 2000 and 2010, which take a value of 1 for the particular year, and 0 otherwise. 
Table 3. Statistics for board of directors

\begin{tabular}{|c|c|c|c|c|c|c|c|c|c|c|c|c|c|}
\hline Variables & Statistics & 2000 & 2001 & 2002 & 2003 & 2004 & 2005 & 2006 & 2007 & 2008 & 2009 & 2010 & Average \\
\hline \multicolumn{14}{|l|}{ Board structure } \\
\hline \multirow[t]{2}{*}{ Board size } & Mean & 6.97 & 6.78 & 6.63 & 6.57 & 6.39 & 6.28 & 6.28 & 6.26 & 6.19 & 6.18 & 6.30 & 6.44 \\
\hline & Std. dev. & 2.39 & 2.39 & 2.37 & 2.44 & 2.37 & 2.33 & 2.28 & 2.23 & 2.25 & 2.30 & 2.24 & \\
\hline \multirow[t]{2}{*}{ Executives } & Mean & 3.69 & 3.50 & 3.35 & 3.23 & 3.10 & 3.03 & 2.99 & 2.90 & 2.79 & 2.76 & 2.74 & 3.10 \\
\hline & Std. dev. & 1.56 & 1.50 & 1.41 & 1.41 & 1.34 & 1.30 & 1.26 & 1.19 & 1.22 & 1.21 & 1.18 & \\
\hline \multirow[t]{2}{*}{ Non-executives } & Mean & 3.28 & 3.28 & 3.27 & 3.33 & 3.29 & 3.24 & 3.28 & 3.36 & 3.39 & 3.42 & 3.55 & 3.34 \\
\hline & Std. dev. & 1.67 & 1.71 & 1.73 & 1.80 & 1.76 & 1.80 & 1.78 & 1.82 & 1.82 & 1.86 & 1.87 & \\
\hline \multirow[t]{2}{*}{ Board independence } & Mean & 46.50 & 47.77 & 48.36 & 49.68 & 50.30 & 50.18 & 50.71 & 51.87 & 53.29 & 53.61 & 54.76 & 50.64 \\
\hline & Std. dev. & 15.91 & 16.10 & 15.80 & 16.80 & 16.72 & 17.63 & 16.56 & 16.79 & 16.60 & 16.81 & 16.55 & \\
\hline \multirow[t]{2}{*}{ CEO/chairman duality } & Mean & 0.89 & 0.89 & 0.90 & 0.91 & 0.92 & 0.93 & 0.93 & 0.95 & 0.96 & 0.95 & 0.96 & 0.93 \\
\hline & Std. dev. & 0.31 & 0.30 & 0.29 & 0.28 & 0.26 & 0.25 & 0.26 & 0.22 & 0.19 & 0.21 & 0.20 & \\
\hline \multicolumn{14}{|l|}{$\underline{\text { Managerial incentives }}$} \\
\hline \multirow[t]{2}{*}{ Executive ownership } & Mean & 12.00 & 11.96 & 11.61 & 10.58 & 10.07 & 10.57 & 10.44 & 10.20 & 9.19 & 8.87 & 8.85 & 10.39 \\
\hline & Std. dev. & 17.15 & 17.02 & 16.64 & 15.82 & 15.48 & 15.75 & 15.87 & 15.83 & 14.77 & 14.50 & 14.89 & \\
\hline \multirow[t]{2}{*}{ Non-executive ownership } & Mean & 3.71 & 4.02 & 4.17 & 4.08 & 4.16 & 4.03 & 4.10 & 4.18 & 4.64 & 4.49 & 4.83 & 4.22 \\
\hline & Std. dev. & 8.34 & 9.00 & 9.18 & 9.03 & 9.37 & 9.36 & 8.89 & 8.96 & 10.01 & 9.77 & 10.04 & \\
\hline \multirow[t]{2}{*}{ Remuneration } & Mean & 5.61 & 5.63 & 5.65 & 5.66 & 5.65 & 5.67 & 5.73 & 5.78 & 5.81 & 5.79 & 5.30 & 5.66 \\
\hline & Std. dev. & 0.49 & 0.50 & 0.50 & 0.51 & 0.57 & 0.55 & 0.52 & 0.52 & 0.52 & 0.55 & 0.60 & \\
\hline Sample size $(\mathrm{N})$ & Sum & 1,381 & 1,387 & 1,373 & 1,294 & 1,415 & 1,537 & 1,550 & 1,501 & 1,363 & 1,204 & 1,118 & 1,375 \\
\hline
\end{tabular}


Table 4. Statistics for directorship characteristics

PANEL A: Director-level statistics across years

\begin{tabular}{cccccccc}
\hline Year & $\begin{array}{c}\text { Total number } \\
\text { of directors } \\
\text { on the boards }\end{array}$ & $\begin{array}{c}\text { Number of } \\
\text { executive } \\
\text { directors }\end{array}$ & $\begin{array}{c}\text { Number of } \\
\text { non-executive } \\
\text { directors }\end{array}$ & $\begin{array}{c}\text { Number of directors with } \\
\text { both executive and } \\
\text { non-executive roles }\end{array}$ & $\begin{array}{c}\text { Number } \\
\text { of } \\
\text { chairmen }\end{array}$ & $\begin{array}{c}\text { Number } \\
\text { of } \\
\text { CEOs }\end{array}$ & $\begin{array}{c}\text { Number } \\
\text { of } \\
\text { CFOs }\end{array}$ \\
\hline 2000 & 8,420 & 5,060 & 3,693 & 333 & 1,183 & 1,210 & 1,181 \\
2001 & 8,239 & 4,818 & 3,747 & 326 & 1,205 & 1,219 & 1,188 \\
2002 & 7,975 & 4,566 & 3,700 & 291 & 1,195 & 1,200 & 1,149 \\
2003 & 7,441 & 4,147 & 3,565 & 271 & 1,133 & 1,118 & 1,057 \\
2004 & 7,816 & 4,332 & 3,824 & 340 & 1,224 & 1,210 & 1,156 \\
2005 & 8,320 & 4,597 & 4,091 & 368 & 1,293 & 1,306 & 1,202 \\
2006 & 8,441 & 4,581 & 4,201 & 341 & 1,298 & 1,344 & 1,246 \\
2007 & 8,127 & 4,311 & 4,145 & 329 & 1,265 & 1,304 & 1,188 \\
2008 & 7,356 & 3,771 & 3,865 & 280 & 1,157 & 1,165 & 1,066 \\
2009 & 6,480 & 3,291 & 3,426 & 237 & 1,026 & 1,031 & 946 \\
2010 & 6,173 & 3,044 & 3,325 & 196 & 958 & 976 & 897 \\
\hline
\end{tabular}

PANEL B: Statistics for multiple directorships at firm-level across years

\begin{tabular}{|c|c|c|c|c|c|c|}
\hline Year & $\begin{array}{c}\text { Number of } \\
\text { directorships } \\
\text { held by executive } \\
\text { directors }\end{array}$ & $\begin{array}{c}\text { Number of } \\
\text { directorships held } \\
\text { by non-executive } \\
\text { directors }\end{array}$ & $\begin{array}{c}\text { Number of } \\
\text { directorships } \\
\text { held by boards } \\
\text { of directors }\end{array}$ & $\begin{array}{l}\text { Number of } \\
\text { directorships } \\
\text { held by } \\
\text { chairman }\end{array}$ & $\begin{array}{c}\text { Maximum } \\
\text { number of } \\
\text { directorships by } \\
\text { any director held }\end{array}$ & $\begin{array}{c}\text { Percentage of } \\
\text { directors with } \\
\text { three or more } \\
\text { directorships }\end{array}$ \\
\hline 2000 & 1.11 & 1.61 & 1.36 & 1.77 & 2.54 & $8 \%$ \\
\hline 2001 & 1.10 & 1.58 & 1.34 & 1.67 & 2.46 & $7 \%$ \\
\hline 2002 & 1.10 & 1.57 & 1.33 & 1.65 & 2.39 & $7 \%$ \\
\hline 2003 & 1.08 & 1.55 & 1.33 & 1.60 & 2.37 & $8 \%$ \\
\hline 2004 & 1.12 & 1.57 & 1.37 & 1.64 & 2.41 & $8 \%$ \\
\hline 2005 & 1.13 & 1.58 & 1.39 & 1.66 & 2.47 & $9 \%$ \\
\hline 2006 & 1.12 & 1.55 & 1.36 & 1.64 & 2.41 & $9 \%$ \\
\hline 2007 & 1.11 & 1.56 & 1.36 & 1.67 & 2.41 & $8 \%$ \\
\hline 2008 & 1.11 & 1.51 & 1.34 & 1.58 & 2.28 & $8 \%$ \\
\hline 2009 & 1.10 & 1.51 & 1.34 & 1.61 & 2.30 & $7 \%$ \\
\hline 2010 & 1.09 & 1.47 & 1.32 & 1.59 & 2.24 & $7 \%$ \\
\hline Overall & 1.10 & 1.55 & 1.35 & 1.64 & 2.39 & $8 \%$ \\
\hline \multicolumn{7}{|c|}{ PANEL C: Statistics for multiple directorships across different indices and markets } \\
\hline \multicolumn{2}{|c|}{ Indices and markets } & $\begin{array}{l}\text { Number of } \\
\text { directors }\end{array}$ & $\begin{array}{l}\text { Number of } \\
\text { directorships }\end{array}$ & $\begin{array}{c}\text { Average } \\
\text { number of } \\
\text { directorships }\end{array}$ & $\begin{array}{l}\text { Number of index or } \\
\text { market only } \\
\text { directors }\end{array}$ & $\begin{array}{l}\text { Percentage of } \\
\text { index or market } \\
\text { only directors }\end{array}$ \\
\hline \multicolumn{2}{|c|}{ FTSE 100} & 2,006 & 9,057 & 4.51 & 964 & $48 \%$ \\
\hline \multicolumn{2}{|c|}{ FTSE Mid-250 } & 4,112 & 15,862 & 3.85 & 1,438 & $35 \%$ \\
\hline \multicolumn{2}{|c|}{ FTSE 350} & 5,198 & 24,919 & 4.79 & 2,952 & $57 \%$ \\
\hline \multicolumn{2}{|c|}{ FTSE MAIN } & 11,742 & 56,208 & 4.78 & 9,650 & $82 \%$ \\
\hline \multicolumn{2}{|c|}{ FTSE AIM } & 10,713 & 41,236 & 3.84 & 8,621 & $80 \%$ \\
\hline \multicolumn{2}{|c|}{ ALL SAMPLE } & 20,363 & 97,444 & 4.78 & & \\
\hline
\end{tabular}


Table 5. Summary of managerial experience

Experience domain

2003

2006-

2009-

Overall

2002

2005

2008

2010

average

The same role experience

Average no. of executive directorships by executive directors

Average no. of non-executive directorships by non-executive directors

Average no. of the same role experience

$\begin{array}{lllll}0.021 & 0.057 & 0.087 & 0.082 & 0.060 \\ 0.194 & 0.233 & 0.259 & 0.216 & 0.226 \\ 0.104 & 0.148 & 0.178 & 0.156 & 0.146 \\ & & & & \\ 0.610 & 0.664 & 0.726 & 0.592 & 0.653 \\ 0.944 & 1.081 & 1.216 & 1.039 & 1.073 \\ 0.777 & 0.890 & 0.995 & 0.845 & 0.879 \\ & & & & \\ 1.026 & 2.023 & 2.650 & 2.735 & 2.053 \\ 1.581 & 3.184 & 4.256 & 4.343 & 3.250 \\ 1.302 & 2.644 & 3.528 & 3.639 & 2.700 \\ & & & & \\ 0.078 & 0.132 & 0.176 & 0.156 & 0.134 \\ 0.048 & 0.071 & 0.088 & 0.081 & 0.071 \\ 0.062 & 0.104 & 0.136 & 0.123 & 0.105 \\ & & & & \\ 0.084 & 0.149 & 0.218 & 0.200 & 0.159 \\ 0.062 & 0.095 & 0.130 & 0.119 & 0.100 \\ 0.072 & 0.128 & 0.179 & 0.166 & 0.133 \\ 0.125 & 0.364 & 0.666 & 0.731 & 0.448 \\ 0.094 & 0.227 & 0.368 & 0.401 & 0.261 \\ 0.108 & 0.307 & 0.533 & 0.590 & 0.366 \\ & & & & \\ 0.085 & 0.155 & 0.209 & 0.189 & 0.157 \\ 0.341 & 0.479 & 0.619 & 0.582 & 0.499 \\ 0.426 & 0.634 & 0.829 & 0.771 & 0.656 \\ 0.011 & 0.023 & 0.032 & 0.032 & 0.024\end{array}$

Average past no. of different firm experience (exec. role by exec.)

Average past no. of different firm experience (non-exec. role by non-exec.)

Average past no. of different firm experience

Average past firm-year experience (exec. role by exec).

Average past firm-year experience (non-exec. role by non-exec.)

Average past firm-year experience

Other role experience

Average no. of executive directorships by non-executive directors

Average no. of non-executive directorships by executive directors

Average no. of other role experience

Average past no. of different firm experience (exec. role by non-exec.)

Average past no. of different firm experience (non-exec. role by exec.)

Average past no. of different firm experience

Average past firm-year experience (exec. role by non-exec)

Average past firm-year experience (non-exec. role by exec.)

Average past firm-year experience

Industry experience

Total no. of executive directors with industry experience

Total no. of non-executive directors with industry experience

Total no. of directors with industry experience

The same-firm experience

Average previous same-firm executive experience by non-executive directors

Average previous same-firm non-executive experience by executive directors

0.016

0.023

0.032

0.029
0.024 
Table 6. Statistics for ownership and shareholder investment characteristics

\begin{tabular}{|c|c|c|c|c|c|c|c|c|c|c|c|}
\hline Shareholders' ownership & 2000 & 2001 & 2002 & 2003 & 2004 & 2005 & 2006 & 2007 & 2008 & 2009 & 2010 \\
\hline \multicolumn{12}{|l|}{ Ownership concentration } \\
\hline Ownership concentration at $3 \%$ & $32.5 \%$ & $33.2 \%$ & $34.8 \%$ & $34.6 \%$ & $35.1 \%$ & $37.8 \%$ & $40.5 \%$ & $44.7 \%$ & $45.1 \%$ & $44.2 \%$ & $46.2 \%$ \\
\hline Ownership concentration at $5 \%$ & $25.5 \%$ & $26.6 \%$ & $27.6 \%$ & $27 \%$ & $27.5 \%$ & $29.9 \%$ & $32.3 \%$ & $35.8 \%$ & $36.5 \%$ & $35.7 \%$ & $37.1 \%$ \\
\hline Ownership concentration at $10 \%$ & $16.2 \%$ & $17.3 \%$ & $17.8 \%$ & $17.4 \%$ & $17.8 \%$ & $19 \%$ & $20.4 \%$ & $21.1 \%$ & $23 \%$ & $22.8 \%$ & $23.8 \%$ \\
\hline \multicolumn{12}{|l|}{$\underline{\text { Shareholders' overall investment characteristics }}$} \\
\hline Average number of major shareholders in a firm & 3.91 & 3.89 & 4.12 & 4.13 & 4.09 & 4.39 & 4.75 & 5.34 & 5.19 & 5.07 & 5.33 \\
\hline Shareholders' total number of industry percentage & $18.7 \%$ & $17.1 \%$ & $20.3 \%$ & $20.3 \%$ & $19.2 \%$ & $21.7 \%$ & $20.9 \%$ & $30.5 \%$ & $22 \%$ & $21.3 \%$ & $24.9 \%$ \\
\hline Shareholders' average industry investment percentage & $53.2 \%$ & $55.1 \%$ & $54.8 \%$ & $53.7 \%$ & $53.6 \%$ & $53.7 \%$ & $55.3 \%$ & $55 \%$ & $57.9 \%$ & $58.9 \%$ & $59.7 \%$ \\
\hline Shareholders' average portfolio investment percentage & $43.4 \%$ & $45.4 \%$ & $44.1 \%$ & $43.3 \%$ & $43.1 \%$ & $41.7 \%$ & $44 \%$ & $42.5 \%$ & $46.8 \%$ & $47.8 \%$ & $48.7 \%$ \\
\hline \multicolumn{12}{|l|}{ Largest shareholder investment characteristics } \\
\hline Largest shareholder ownership & $14.4 \%$ & $14.9 \%$ & $15 \%$ & $15 \%$ & $14.9 \%$ & $15.7 \%$ & $16.3 \%$ & $17.1 \%$ & $17.7 \%$ & $17.9 \%$ & $18.4 \%$ \\
\hline Largest shareholder industry shareholdings & $42.2 \%$ & $40.5 \%$ & $42.2 \%$ & $41.2 \%$ & $39 \%$ & $42.7 \%$ & $41.3 \%$ & $42.4 \%$ & $39.5 \%$ & $40.6 \%$ & $41.2 \%$ \\
\hline Largest shareholder firm-portfolio investment percentage & $45.2 \%$ & $46.9 \%$ & $45.8 \%$ & $45.6 \%$ & $46.1 \%$ & $45 \%$ & $48.5 \%$ & $49.4 \%$ & $51.5 \%$ & $50.7 \%$ & $53.9 \%$ \\
\hline Number of firms & 1,381 & 1,387 & 1,374 & 1,294 & 1,422 & 1,538 & 1,551 & 1,501 & 1,363 & 1,204 & 1,118 \\
\hline
\end{tabular}


Table 7. Results of multivariate analysis

\begin{tabular}{|c|c|c|c|}
\hline \multicolumn{4}{|l|}{ Dependent variable: $\operatorname{TOBINQ}_{i, t}$} \\
\hline Independent variables: & Model 1 & Model 2 & Model 3 \\
\hline \multicolumn{4}{|l|}{ Corporate board variables } \\
\hline$B O A R D S I Z E_{i t}$ & $0.212(1.50)$ & $0.195(1.35)$ & $0.192(1.33)$ \\
\hline BINDEPENCE $_{i, t-1}^{1,1}$ & $0.0087^{\star * \star}(7.33)$ & $0.0107^{* \star *}(8.34)$ & $0.0106^{* * *}(8.31)$ \\
\hline$D U A L_{i t-1}$ & $0.00856(0.14)$ & $0.020(0.31)$ & $0.0193(0.30)$ \\
\hline DRCTRSHIP & $-0.0848^{*}(-1.70)$ & & \\
\hline EXEDRCTRSHIP & & $0.175^{*}(1.79)$ & $0.173^{*}(1.77)$ \\
\hline NONEXEDRCTRSHIP & & $-0.0735^{\star * *}(-2.87)$ & $-0.0738^{\star * \star}(-2.88)$ \\
\hline TASKEXP & $0.189^{*}(1.66)$ & & \\
\hline EXETASKEXP & & $-0.050(-0.55)$ & $-0.0538(-0.60)$ \\
\hline NONEXETASKEXPP & & $0.147^{\star \star}(2.32)$ & $0.150^{\star *}(2.37)$ \\
\hline OTHERTASKEXP & $0.325^{\star \star \star}(3.66)$ & & \\
\hline EXEOTHERTASKEXP & & $-0.0670(-0.61)$ & $-0.0618(-0.57)$ \\
\hline NONEXEOTHERTASKEXP $P_{i t-1}$ & & $0.188^{\star * \star}(3.37)$ & $0.193^{\star \star \star}(3.44)$ \\
\hline INDUSTRYEXP $_{i, t-1}$ & $-0.0565(-0.52)$ & & \\
\hline EXEINDUSTRYYXXP & & $-0.0401(-0.44)$ & $-0.0452(-0.49)$ \\
\hline NONEXEINDUSTRYEXP $P_{i, t-1}$ & & $0.0475(0.79)$ & $0.0460(0.76)$ \\
\hline SAMEFIRMEXP & $-0.238(-1.18)$ & & \\
\hline EXESAMEFIRMEXP $P_{i, t-1}$ & & $-0.104(-0.77)$ & $-0.109(-0.81)$ \\
\hline NONEXESAMEFIRMEXP & & $0.176(0.84)$ & $0.173(0.83)$ \\
\hline $\operatorname{DIROWN}_{i, t-1}$ & $0.00311(1.05)$ & & \\
\hline DIROWN $N_{i, t-1}^{2,-1}$ & $-0.0000117(-0.24)$ & & \\
\hline EXEOWN $_{i, t-1}$ & & $0.0141^{* * *}(4.48)$ & $0.0139^{\star \star \star}(4.42)$ \\
\hline NONEXEOWN $N_{i t-1}$ & & $-0.000202(-0.10)$ & $-0.000407(-0.21)$ \\
\hline EXEOWN $_{i, t-1}^{2}$ & & $-0.000201^{\star \star *}(-4.07)$ & $-0.000198^{* * *}(-4.03)$ \\
\hline REMUNERATION $_{i, t-1}$ & $0.745^{\star \star \star}(10.54)$ & $0.755^{\star * \star}(10.60)$ & $0.757^{\star \star \star}(10.59)$ \\
\hline \multicolumn{4}{|l|}{$\underline{\text { Shareholder variables }}$} \\
\hline $\begin{array}{l}\text { OWNCON }_{i, t-1} \\
\quad \text { LRGSTSHRHLDR }\end{array}$ & $-0.00261^{* * *}(-3.06)$ & $-0.00246^{\star \star \star}(-2.87)$ & $\begin{array}{l}-0.00265^{\star \star *}(-3.07) \\
-0.0635^{\star *}(-1.98)\end{array}$ \\
\hline SHRINTERLOCKS ${ }_{i, t-1}$ & $0.0474^{\star * *}(3.04)$ & $0.0437^{\star \star *}(2.80)$ & $0.0469^{\star * \star}(2.99)$ \\
\hline SHRLOCKING ${ }_{i, t-1}$ & $0.0665^{*}(1.90)$ & $0.0664^{*}(1.90)$ & $0.0380(0.99)$ \\
\hline \multicolumn{4}{|l|}{ Control variables } \\
\hline FIRMSIZE $_{i t-1}$ & $-0.411^{* * *}(-12.79)$ & $-0.399^{\star * *}(-12.35)$ & $-0.397^{\star * *}(-12.35)$ \\
\hline $\begin{array}{l}\text { INDUSTRY } \\
\text { YEAR } \\
\text { Constant }\end{array}$ & $\begin{array}{c}\text { Yes } \\
\text { Yes } \\
-1.692^{* * *}(-4.53)\end{array}$ & $\begin{array}{c}\text { Yes } \\
\text { Yes } \\
-1.992^{* * *}(-5.40)\end{array}$ & $\begin{array}{c}\text { Yes } \\
\text { Yes } \\
-1.960^{* * *}(-5.33)\end{array}$ \\
\hline Adjusted $R^{2}(\%)$ & $13.8 \%$ & $14.1 \%$ & $14.2 \%$ \\
\hline Number of observations & 6,175 & 6,175 & 6,175 \\
\hline
\end{tabular}

Notes: This table reports estimated coefficients and $t$-statistics in the parentheses. The pooled OLS models are tested using White's corrected heteroscedasticity robust regressions. Independent variables are one-year lagged. ${ }^{* \star *},{ }^{* *}$ and ${ }^{*}$ stand for significance at the $1 \%, 5 \%$ and $10 \%$ levels, respectively. 
Table 8. Results of further analysis

\begin{tabular}{|c|c|c|c|c|c|}
\hline Dependent variable: $\operatorname{TOBINQ}_{i, t}$ & & & & & \\
\hline Independent variables: & Model 4 & Model 5 & Model 6 & Model 7 & Model 8 \\
\hline \multicolumn{6}{|l|}{$\underline{\text { Corporate board variables }}$} \\
\hline$B O A R D S I Z E_{i, t-1}$ & $0.199(1.41)$ & $0.218(1.51)$ & $0.178(1.26)$ & $0.219(1.53)$ & $0.198(1.38)$ \\
\hline BINDEPENCE $_{i, t-1}$ & $0.00916^{\star \star \star}(7.68)$ & $0.0106^{\star \star \star}(8.28)$ & $0.0104^{\star \star \star}(8.29)$ & $0.0107^{\star \star \star}(8.50)$ & $0.0106^{\star * *}(8.29)$ \\
\hline$D U A L_{i, t-1}$ & $0.0128(0.20)$ & $0.0224(0.35)$ & $0.0147(0.24)$ & $0.0129(0.20)$ & $0.0163(0.25)$ \\
\hline$B R D C A P A B I L I T Y_{i, t-1}$ & $0.0179^{\star *}(2.02)$ & & & & \\
\hline EXECAPABILITITY & & $0.0107(1.19)$ & $0.00983(1.10)$ & $0.0102(1.13)$ & $0.0109(1.21)$ \\
\hline NONEXECAPABILITY $Y_{i, t-1}$ & & $0.0169^{*}(1.77)$ & $0.0161^{*}(1.69)$ & $0.0189^{\star \star}(1.98)$ & $0.0159^{*}(1.67)$ \\
\hline $\operatorname{DIROWN}_{i, t-1}$ & $0.00287(0.98)$ & & & & \\
\hline $\operatorname{DIROWN} N_{i, t-1}^{2 t}$ & $-0.0000074(-0.16)$ & & & & \\
\hline EXEOWN $_{i, t-1}$ & & $0.0135^{\star * *}(4.30)$ & $0.0144^{* * *}(4.68)$ & $0.0136^{* * *}(4.37)$ & $0.0128^{\star * *}(4.05)$ \\
\hline NONEXEOWN & & $-0.000281(-0.15)$ & $0.000121(0.06)$ & $-0.000197(-0.10)$ & $-0.000156(-0.08)$ \\
\hline $\operatorname{EXEOWN}_{i, t-1}^{2}$ & & $-0.000189^{\star * \star}(-3.84)$ & $-0.000199^{\star \star *}(-4.09)$ & $-0.000191^{* * *}(-3.90)$ & $-0.000177^{\star * *}(-3.53)$ \\
\hline REMUNERATION ${ }_{i, t-1}$ & $0.753^{\star \star \star}(10.51)$ & $0.752^{\star \star *}(10.45)$ & $0.783^{\star \star *}(11.26)$ & $0.780^{\star \star}(11.08)$ & $0.754^{\star \star *}(10.45)$ \\
\hline \multicolumn{6}{|l|}{$\underline{\text { Shareholder variables }}$} \\
\hline OWNCON $_{i, t-1}$ & $-0.00280^{\star \star \star}(-3.29)$ & $-0.00260^{\star * *}(-3.04)$ & $-0.00257^{\star \star \star}(-3.06)$ & $-0.00266^{\star \star *}(-3.11)$ & $-0.00251^{* * *}(-2.93)$ \\
\hline SHRINTERLOCKS $_{i, t-1}$ & $0.0491^{* * *}(3.15)$ & $0.0459^{* \star *}(2.94)$ & $0.0505^{\star * *}(3.28)$ & $0.0504^{\star \star *}(3.21)$ & $0.0437^{\star \star \star}(2.80)$ \\
\hline SHRLOCKING ${ }_{i, t-1}$ & $0.0666^{*}(1.90)$ & $0.0635^{\star}(1.81)$ & $0.0136^{*}(1.94)$ & $0.0608^{\star}(1.74)$ & $0.0643^{\star}(1.84)$ \\
\hline \multicolumn{6}{|l|}{$\underline{\text { Control variables }}$} \\
\hline FIRMSIZE $_{i, t-1}$ & $-0.409^{* \star \star}(-12.84)$ & $-0.401^{* * *}(-12.59)$ & $-0.426^{* \star *}(-13.43)$ & $-0.409^{\star \star *}(-12.91)$ & $-0.408^{\star * *}(-12.72)$ \\
\hline LEVERAGE $_{i, t-1}$ & & & $0.506^{* * *}(4.16)$ & & \\
\hline SHORTDEBT $_{i, t-1}$ & & & & $0.532^{\star \star *}(2.97)$ & \\
\hline DPAYOUT & & & & & $1.053^{* *}(2.16)$ \\
\hline $\begin{array}{l}\text { INDUSTRY } \\
\text { YEAR }\end{array}$ & $\begin{array}{l}\text { Yes } \\
\text { Yes }\end{array}$ & $\begin{array}{l}\text { Yes } \\
\text { Yes }\end{array}$ & $\begin{array}{l}\text { Yes } \\
\text { Yes }\end{array}$ & Yes & $\begin{array}{l}\text { Yes } \\
\text { Yes }\end{array}$ \\
\hline $\begin{array}{c}Y E A R \\
\text { Constant }\end{array}$ & $\begin{array}{l}\text { Yes } \\
-1.623^{* * *}(-4.77)\end{array}$ & $-1.782^{* * *}(-5.23)$ & $-1.846^{* * *}(-5.64)$ & $\begin{array}{c}\text { Yes } \\
-1.953^{* * *}(-5.89)\end{array}$ & $\begin{array}{c}\text { Yes } \\
-1.908^{* * *}(-5.08)\end{array}$ \\
\hline Adjusted $R^{2}(\%)$ & $13.7 \%$ & $13.9 \%$ & $14.8 \%$ & $14.2 \%$ & $14.5 \%$ \\
\hline Number of observations & 6,175 & 6,175 & 6,175 & 6,175 & 6,175 \\
\hline
\end{tabular}

Notes: This table reports estimated coefficients and $t$-statistics in the parentheses. The pooled OLS models are tested using White's corrected heteroscedasticity robus regressions. Independent variables are one-year lagged. ${ }^{* *},{ }^{* *}$ and ${ }^{*}$ stand for significance at the $1 \%, 5 \%$ and $10 \%$ levels, respectively. 
Figure 1. Integrated analytical governance-performance model

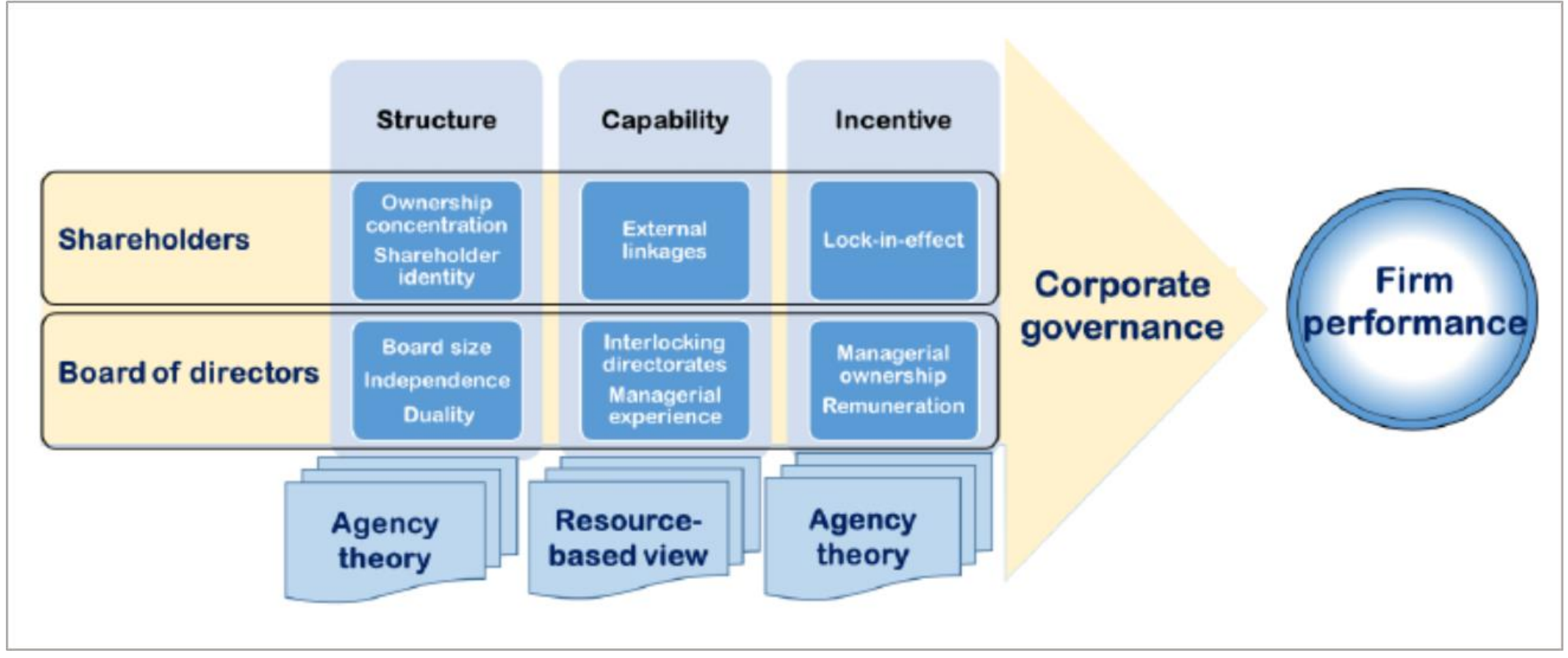


Figure 2. Summary of industry-level Tobin's $Q$ (firm performance) averages

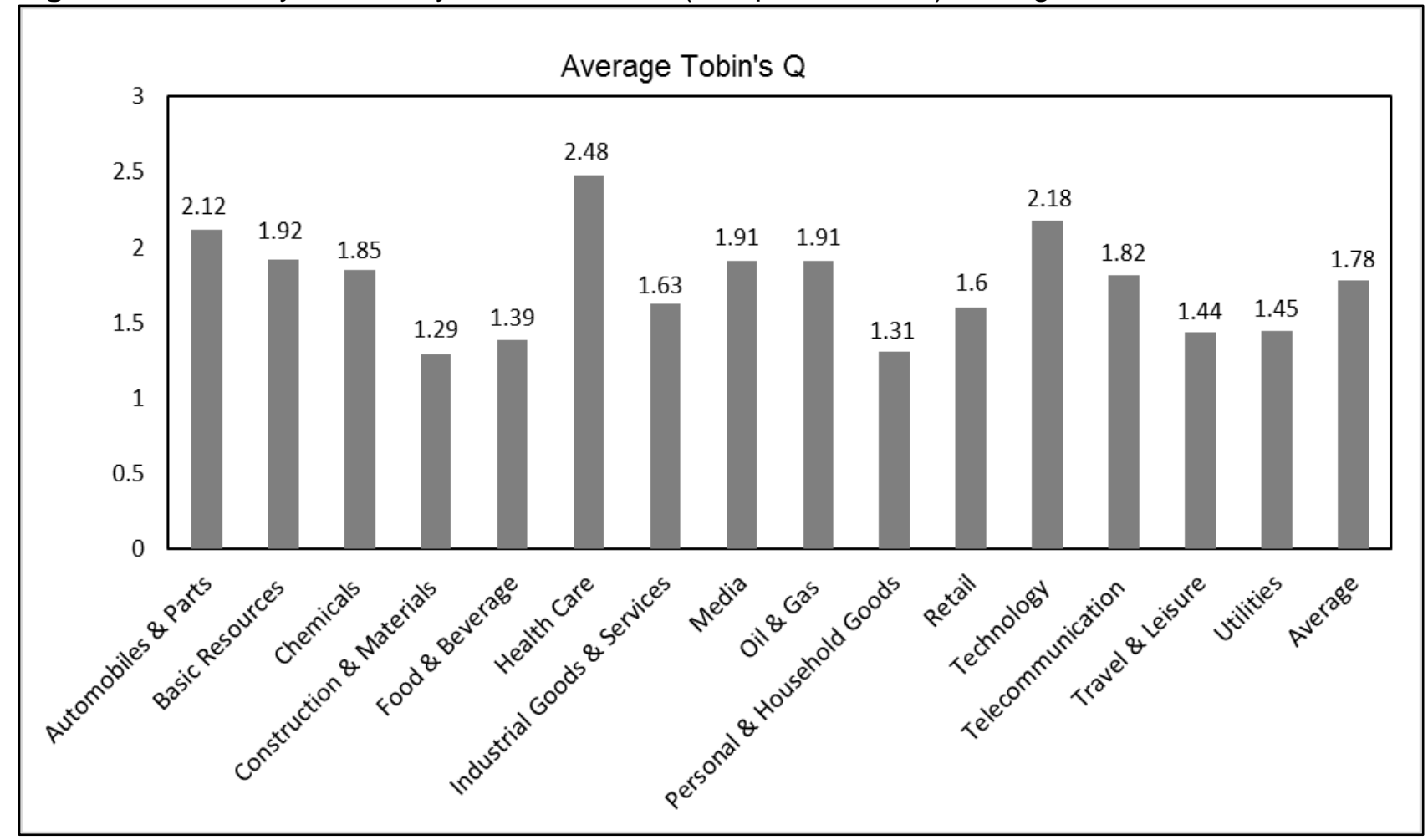

